\title{
Moving on From Sipuleucel-T: New Dendritic Cell Vaccine Strategies for Prostate Cancer
}

\author{
Sarah I. M. Sutherland ${ }^{1,2,3,4}$, Xinsheng Ju ${ }^{1,2}$, L. G. Horvath ${ }^{2,4,5}$ and Georgina J. Clark ${ }^{1,2 *}$ \\ ${ }^{1}$ Dendritic Cell Research, ANZAC Research Institute, Concord, NSW, Australia, ${ }^{2}$ Faculty of Medicine and Health, University \\ of Sydney, Sydney, NSW, Australia, ${ }^{3}$ Department of Medical Oncology, Concord Repatriation General Hospital, Concord, \\ NSW, Australia, ${ }^{4}$ Department of Medical Oncology, Chris O'Brien Lifehouse, Camperdown, NSW, Australia, ${ }^{5}$ Garvan Institute \\ of Medical Research, Darlinghurst, NSW, Australia
}

Tumors evade the immune system though a myriad of mechanisms. Using checkpoint inhibitors to help reprime $T$ cells to recognize tumor has had great success in malignancies including melanoma, lung, and renal cell carcinoma. Many tumors including prostate cancer are resistant to such treatment. However, Sipuleucel-T, a dendritic cell (DC) based immunotherapy, improved overall survival (OS) in prostate cancer. Despite this initial success, further DC vaccines have failed to progress and there has been limited uptake of Sipuleucel-T in the clinic. We know in prostate cancer (PCa) that both the adaptive and the innate arms of the immune system contribute

OPEN ACCESS

Edited by:

Irina Caminschi,

Monash University, Australia

Reviewed by:

Yifan Zhan,

Walter and Eliza Hall Institute of

Medical Research, Australia

Richard A. Kroczek,

Robert Koch Institute (RKI), Germany

*Correspondence:

Georgina J. Clark

georgina.clark@sydney.edu.au

Specialty section:

This article was submitted to Antigen Presenting Cell Biology,

a section of the journal

Frontiers in Immunology

Received: 14 December 2020 Accepted: 12 February 2021 Published: 29 March 2021

Citation:

Sutherland SIM, Ju X, Horvath LG and Clark GJ (2021) Moving on From Sipuleucel-T: New Dendritic Cell Vaccine Strategies for Prostate Cancer. Front. Immunol. 12:641307. doi: 10.3389/fimmu.2021.641307 to the immunosuppressive environment. This is at least in part due to dysfunction of DC that play a crucial role in the initiation of an immune response. We also know that there is a paucity of DC in PCa, and that those there are immature, creating a tolerogenic environment. These attributes make PCa a good candidate for a DC based immunotherapy. Ultimately, the knowledge gained by much research into antigen processing and presentation needs to translate from bench to bedside. In this review we will analyze why newer vaccine strategies using monocyte derived DC (MoDC) have failed to deliver clinical benefit, particularly in $\mathrm{PCa}$, and highlight the emerging antigen loading and presentation technologies such as nanoparticles, antibody-antigen conjugates and virus co-delivery systems that can be used to improve efficacy. Lastly, we will assess combination strategies that can help overcome the immunosuppressive microenvironment of PCa.

Keywords: dendritic cell, vaccine, prostate cancer, tumor, immune system, immunotherapy

\section{INTRODUCTION}

Immune evasion has long been recognized as a problem in prostate cancer (PCa). To date checkpoint inhibitors that aim to release the "brakes" on $\mathrm{T}$ cell expansion have proved disappointing (1-3). Dendritic cells (DC) bridge the gap between the innate and adaptive immune response, playing a crucial role in tipping the direction toward inflammation or tolerance. Manipulating this balance through DC vaccine therapy has therapeutic potential. This is not a novel concept (4); in 2010, Sipuleucel-T was the first DC therapy approved by the FDA for the treatment of metastatic castrate resistant prostate cancer (mCRPCa) (5). Our understanding of DC biology has vastly increased over the last decade, yet no further DC therapy has been FDA approved. 


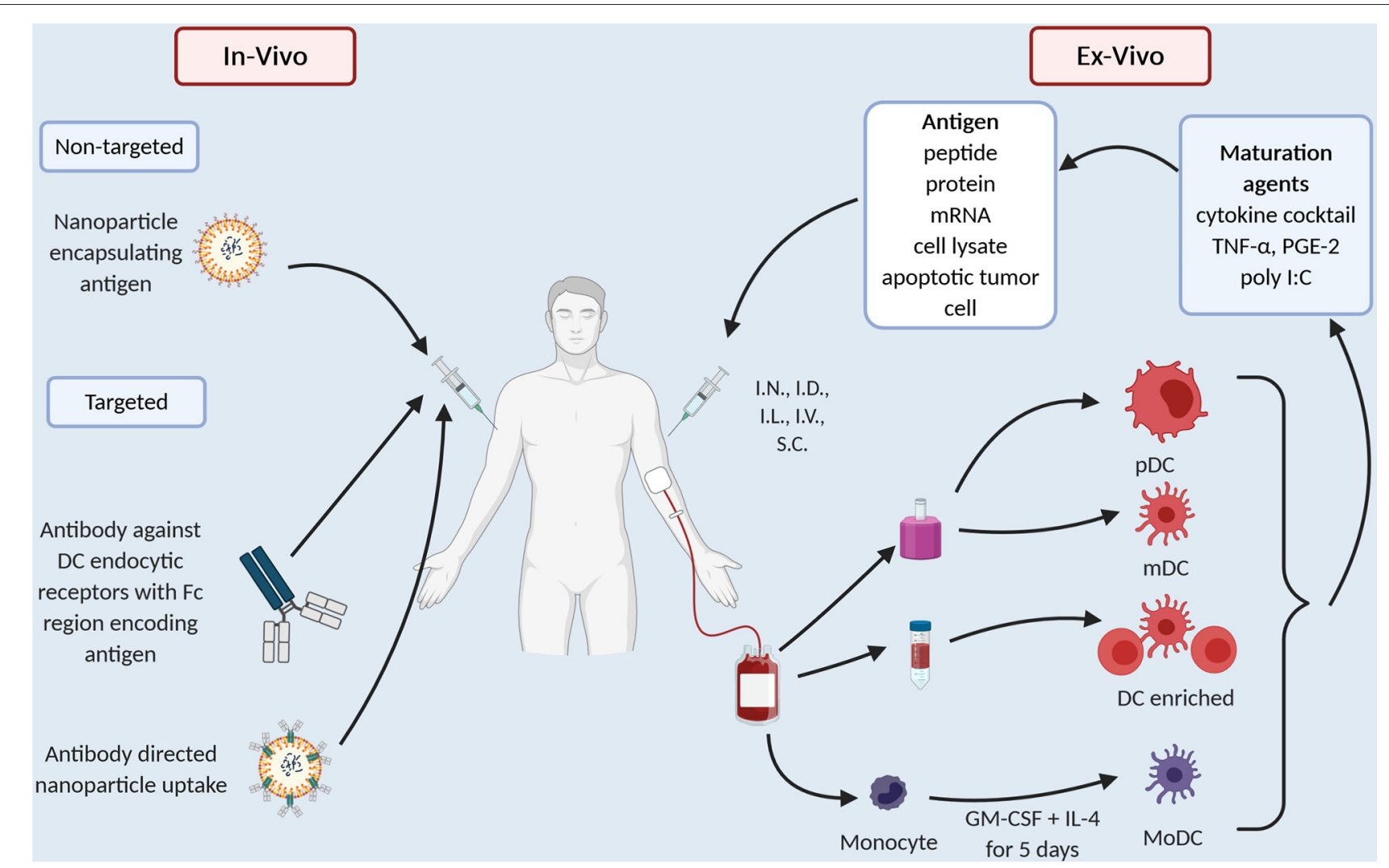

FIGURE 1 | Current dendritic cell vaccination technologies.

In this review we will assess the strengths and weaknesses of prior approaches and then look at the potential of new technologies to drive improvements. Here we review how these technologies apply to PCa and suggest combination therapies that might overcome the immunosuppressive microenvironment leading to better clinical outcomes.

\section{DENDRITIC CELL VACCINATION IN PCA}

In PCa DC are dysfunctional and key orchestrators of its immunosuppressive microenvironment (6-11). Sipuleucel-T demonstrates that taking antigen presenting cells (APC) from PCa patients, pulsing them with tumor peptide and inducing their maturation prior to returning them back to patients, primes $\mathrm{T}$ cells that track to the tumor itself (12). In a pooled analysis of two, phase III, randomized control trials (RCT) in minimally or asymptomatic mCRPCa, Sipuleucel-T, improved overall survival (OS) to 23 months from 19 months [Hazard Ratio (HR) 1.50, 95\% CI: $1.10-2.05, p=0.01$ ] (13). This OS benefit was corroborated by a third trial where OS was similarly increased by 4.1 months (5). Despite such promise the use of Sipuleucel-T in the clinic remains low.

One reason is skepticism over the trial results. It has been proposed that the control arm did worse than anticipated and that the benefit seen was in fact due to the harm of apheresis, where fewer PBMC were returned to patients in the control arm than the treatment arm (14). This has not been helped by a plethora of further DC-based therapy trials performed with monocyte-derived DC (MoDC) that despite showing immunological responses, have failed to show real clinical benefit.

\section{MoDC Vaccination}

The common technical issue in any DC preparation is the low prevalence of DC in the peripheral blood, ranging 0.1$1 \%$ of peripheral blood mononuclear cells (PBMC) (15). Thus, early DC preparations such as Sipuleucel-T use a density gradient to prepare an APC enriched preparation (Figure 1). "Second generation" DC vaccines use strategies that differentiate monocytes into dendritic like cells called MoDC (Figure 1), creating a more readily available source of APC as monocytes make up $\sim 10 \%$ of PBMC compared to $1 \%$ for DC. MoDC are prepared by separating $\mathrm{CD} 14^{+}$cells from $\mathrm{PBMC}$ either by their ability to adhere to plastic overnight culture or by antiCD14 microbeads and magnetic separation. CD14 ${ }^{+}$cells are then cultured with cytokines, typically GM-CSF and IL-4 for 4-5 days, after which they display an immature DC like phenotype (16). When cultured with tumor antigen in the form of peptide or protein these cells cross-present and induce $\mathrm{T}$ cell proliferation (16). In melanoma patients, whilst only a small proportion i.e., 
TABLE 1 | Published DC vaccination trials in prostate cancer.

\begin{tabular}{|c|c|c|c|c|c|c|c|c|}
\hline $\begin{array}{l}\text { Cell Type and } \\
\text { Maturation }\end{array}$ & Antigen & Trials & Population & Phase & Pt \# & Intervention: & $\begin{array}{l}\text { Route } \pm \\
\text { adjuvant }\end{array}$ & Outcome \\
\hline \multirow[t]{9}{*}{ Immature MoDC } & & & & & & Peptide (HLA-A2) & & \\
\hline & $\begin{array}{l}\text { PSMA-P1 and } \\
\text { PSMA-P2 }\end{array}$ & Murphy et al. (18) & CRPCa & 1 & 51 & $\begin{array}{l}\text { Arm 1+2: } \\
\text { Peptide }(n=20) \\
\text { Arm 3: DC }(n=12) \\
\text { Arm 4 + 5: DC } \\
\text { Vaccine }(n=19) \\
\text { Arm 1 + 4: PSMA-1 } \\
\text { Arm 2 + 5: PSMA-2 }\end{array}$ & I.V. & $\begin{array}{l}\text { Primary: } \\
\text { Safety: (hypotension 24/51, fatigue } \\
\text { 3/51 } \\
\text { Secondary: } \\
\text { Immunological: T cell proliferation in } \\
\text { response } \\
\text { to peptide ( } \uparrow \text { in HLA-A2+ DC vac pts) } \\
\text { Clinical: Peptide (PR 2/19, SD 2/19) } \\
\text { DC (PR 0/12, SD 2/12) } \\
\text { DC Vaccine (PR 5/20, SD 3/20) }\end{array}$ \\
\hline & $\begin{array}{l}\text { PSMA-P1 and } \\
\text { PSMA-P2 }\end{array}$ & Murphy et al. (19) & CRPCa & $\|$ & 33 & & I.V. & Clinical: CR 2/25, PR 6/25, 1/25 SD \\
\hline & $\begin{array}{l}\text { PSMA-P1 and } \\
\text { PSMA-P2 }\end{array}$ & Murphy et al. (20) & Recurrent CSPCa & $\|$ & 41 & & I.V. & Clinical: CR 1/37, PR 10/37 \\
\hline & $\begin{array}{l}\text { PSMA-P1 and } \\
\mathrm{P} 2+\mathrm{KLH}\end{array}$ & Murphy et al. (21) & CRPCA & $\|$ & 17 & & I.V. & $\begin{array}{l}\text { Safety: fever, fatigue, muscle cramps } \\
\text { Clinical: CR 1/17, PR } 3 / 17\end{array}$ \\
\hline & $\mathrm{PSMA}_{4-12}$ & Knight et al. (22) & $\begin{array}{l}\text { CRPCa-HLA-A2 } \\
\text { positive }\end{array}$ & I & 12 & $\begin{array}{l}\text { Cells irradiated prior } \\
\text { to infusion }\end{array}$ & S.C. & $\begin{array}{l}\text { Safety: Fatigue } 4 / 12 \text {, fever } 4 / 12 \text {, pain } \\
4 / 12 \\
\text { Immunological: ELISPOT 0/12 }\end{array}$ \\
\hline & $\mathrm{PSA}_{146-154}$ & $\begin{array}{l}\text { Perambakam et al. } \\
\text { (23) }\end{array}$ & CSPCa & । & 28 & $\begin{array}{l}\text { Cohort 1: high risk } \\
\text { locally advanced } \\
\text { disease } \\
\text { Cohort 2: metastatic } \\
\text { disease } \\
\text { Arm A: Peptide + } \\
\text { GM-CSF (I.D.) } \\
\text { Arm B: MoDC }\end{array}$ & I.L. & $\begin{array}{l}\text { Immunological: DTH Arm A 9/14 Arm } \\
\text { B: 5/14 }\end{array}$ \\
\hline & & & & & & Protein & & \\
\hline & PSA & Barrou et al. (24) & bcrCSPCa & $\|$ & 26 & $\begin{array}{l}\text { Used GM-CSF and } \\
\text { IL-13 rather than } \\
\text { IL-14 }\end{array}$ & I.V., S.C., I.D. & $\begin{array}{l}\text { Safety: } 3 / 24 \text { macular rash, } 2 / 24 \text { G2 } \\
\text { increase in bilirubin, } 1 / 24 \text { asthenia, } \\
\text { 1/24 halitosis } \\
\text { Clinical: Circulating tumor cells 6/6. } \\
\text { PSA response 0/24. } \\
\text { Immunological: ELISPOT response to } \\
\text { PSA 4/24 developed a response on } \\
\text { treatment } \\
\text { No antibody response. }\end{array}$ \\
\hline
\end{tabular}


TABLE 1 | Continued

\begin{tabular}{|c|c|c|c|c|c|c|c|c|}
\hline $\begin{array}{l}\text { Cell Type and } \\
\text { Maturation }\end{array}$ & Antigen & Trials & Population & Phase & $\mathrm{Pt} \#$ & Intervention: & $\begin{array}{l}\text { Route } \pm \\
\text { adjuvant }\end{array}$ & Outcome \\
\hline & & & & & & Cell-lysate & & \\
\hline & LNCaP, DU145 & Pandha et al. (25) & CRPCa & $1 / 11$ & 11 & & I.D. & $\begin{array}{l}\text { Primary: } \\
\text { Feasibility: Vaccine produced in 11/11 } \\
\text { pts } \\
\text { Safety: nil significant local or systemic } \\
\text { toxicity } \\
\text { Secondary: } \\
\text { Clinical: PSA response 0/11, } \uparrow \text { PSADT } \\
\text { in } 3 / 11 \\
\text { Radiological: CR 0/11, PR 0/11, SD } \\
\text { 4/11 } \\
\text { Immunological: DTH response 0/11, } \\
\text { ELISPOT response 6/11 }\end{array}$ \\
\hline & & & & & & mRNA & & \\
\hline & PSA & Heiser et al. (26) & $\mathrm{mPrCa}$ & I & 16 & & I.V., I.D. & $\begin{array}{l}\text { Feasibility: assigned cell dose given } \\
12 / 13 \text { patients } \\
\text { Safety: fever and flu-like sx } 4 / 13 \text {, } \\
\text { injection site reaction } 4 / 13 \\
\text { Immunological Response: } \\
\text { ELISPOT } 9 / 9\end{array}$ \\
\hline Mature MoDC & & & & & & Peptide (HLA-A2) & & \\
\hline TNF- $\alpha$, PGE-2 & $\begin{array}{l}\text { PSCA }_{14-22} \\
\text { PSA1 }_{141-150} \\
\text { PSA2 } 146-154 \\
\text { PSA3 }{ }_{154-163}\end{array}$ & $\begin{array}{l}\text { Thomas-Kaskel } \\
\text { et al. (27) }\end{array}$ & $\begin{array}{l}\text { CRPCa } \\
\text { HLA-A2+ }\end{array}$ & $1 / 11$ & 12 & $\begin{array}{l}\text { Arm 1: PSCA peptide } \\
+ \text { PSA peptides } \\
\text { Arm 2: cell } \\
\text { penetrating peptide } \\
\text { (CPP)-PSCA + } \\
\text { PSA peptides }\end{array}$ & S.C. & $\begin{array}{l}\text { Primary: } \\
\text { Feasibility: } 10 / 12 \text { pts received at least } \\
3 \text { vaccinations } \\
\text { Safety: no reported toxicity } \\
\text { Secondary: } \\
\text { Immunological: DTH to tumor peptide } \\
\text { 5/10, Tetramer } 1 / 10 \\
\text { Clinical: SD } 4 / 10\end{array}$ \\
\hline & $\begin{array}{l}\text { PSA1 } 141-150 \\
\text { PSA2 } 146-154 \\
\text { PSA3 }{ }_{154-163}\end{array}$ & $\begin{array}{l}\text { Hildenbrand et al. } \\
\text { (28) }\end{array}$ & CRPCa & I & 15 & & I.D. & $\begin{array}{l}\text { Primary: } \\
\text { Clinical Response: PR 1/12, SD 4/12 } \\
\text { Biochemical Response: 1/12, } \\
\text { } P S A D T \\
\text { Secondary: } \\
\text { QOL: no change } \\
\text { Immunological: DTH response: 9/12 } \\
\text { Feasibility: } 12 / 15 \text { enrolled evaluable } \\
\text { Safety: fever 11/12, local erythema } \\
\text { 11/12, 6/12 bone pain, 3/12 slight } \\
\text { articular pain, } 1 / 12 \text { insomnia }\end{array}$ \\
\hline
\end{tabular}


TABLE 1 | Continued

\begin{tabular}{|c|c|c|c|c|c|c|c|c|}
\hline $\begin{array}{l}\text { Cell Type and } \\
\text { Maturation }\end{array}$ & Antigen & Trials & Population & Phase & Pt \# & Intervention: & $\begin{array}{l}\text { Route } \pm \\
\text { adjuvant }\end{array}$ & Outcome \\
\hline & $\begin{array}{l}\text { PSA }_{146-154} \\
\text { PSMA }_{4-12} \\
\text { PAP }_{299-307}\end{array}$ & Zhuang et al. (29) & CRPCa & 1 & 16 & & S.C. & $\begin{array}{l}\text { Immunological: DTH response 4/12 } \\
\text { Clinical: PR 3/16, 7/16 SD }\end{array}$ \\
\hline Poly I:C & $\begin{array}{l}\text { PSMA }_{154-163} \\
\text { Survivin 95-104 }\end{array}$ & Xi et al. (30) & Non-mCRPCa & $\|$ & 21 & $\begin{array}{l}\text { Arm 1: DC vaccine ( } n \\
=11) \\
\text { Arm 2: Docetaxel and } \\
\text { prednisone }(n=11)\end{array}$ & S.C. & $\begin{array}{l}\text { Safety: local reaction } 4 / 11 \text {, } \\
\text { Immunological: DTH response } 11 / 11 \text {, } \\
\text { ELISPOT increased compared to } \\
\text { docetaxel arm ( } p=0.048) \\
\text { Clinical: DC arm vs. docetaxel } \\
\text { PR: } 3 / 11 \text { vs. } 0 / 11 \text {, SD 6/11 vs. } 5 / 11\end{array}$ \\
\hline \multirow[t]{3}{*}{ Cytokine cocktail } & $\begin{array}{l}\text { PSA3 }_{154-163} \\
\text { PSMA }_{4-12} \\
\text { Prostein }_{31-39} \\
\text { Survivin }_{950104} \\
\text { Trp-p8 } 187-195\end{array}$ & Fuessel et al. (31) & CRPCa & 1 & 8 & & I.V., I.D. & $\begin{array}{l}\text { Safety: local reaction } \\
\text { Clinical: PSA response 1/8 } \\
\text { Immunological: ELISPOT 4/8 }\end{array}$ \\
\hline & $\begin{array}{l}\text { PSCA }_{14-22} \\
\text { PAP }_{299-307} \\
\text { PSMA }_{4-12} \\
\text { PSA }_{154-163}\end{array}$ & $\begin{array}{l}\text { Waeckerle-Men } \\
\text { et al. (32) }\end{array}$ & mCRPCa & 1 & 6 & & I.D. & $\begin{array}{l}\text { Safety: local reaction 5/6 } \\
\text { Clinical: } \uparrow \text { PSADT 3/6 } \\
\text { Immunological: ELISPOT 3/6, } \\
\text { DTH 3/6 }\end{array}$ \\
\hline & & & & & & Protein & & \\
\hline \multirow[t]{2}{*}{ Cytokine cocktail } & Tn-MUC1 + KLH & $\begin{array}{l}\text { Scheid et al. (33) } \\
\text { NCT00852007 }\end{array}$ & Non-mCRPCa & I/II & 17 & Tn-MUC1+ & I.N., I.D. & $\begin{array}{l}\text { Safety: local reaction 16/17, G1 } \\
\text { fatigue 1/, G1 insomnia } \\
\text { Clinical Response: biochemical 0/16, } \\
\text { PSADT increased in 11/16. } \\
\text { Immunological: Intracellular response } \\
\text { in CD4+ CD8 T cells in 2/16, CD4 in } \\
1 / 16, \text { CD8 in 2/16. }\end{array}$ \\
\hline & & & & & & mRNA & & \\
\hline \multirow[t]{2}{*}{ Cytokine cocktail } & $\begin{array}{l}\text { mRNA from } \\
\text { DU145, LNCaP, } \\
\text { PC3 }\end{array}$ & Mu et al. (34) & CRPCa & $|/| \mid$ & 20 & $\begin{array}{l}\text { Arm A: I.N. }(n=10) \\
\text { Arm B: I.D. }(n=9)\end{array}$ & I.N. or I.D. & $\begin{array}{l}\text { Safety: injection site reactions } \\
\text { Immune response: ELISPOT } 10.19 \\
\text { Clinical: Reduced PSA slope } 13 / 19\end{array}$ \\
\hline & & & & & & Cell lysate & & \\
\hline Cytokine cocktail & $\begin{array}{l}\text { DU145 } \\
\text { LNCaP } \\
\text { PC3 }\end{array}$ & Reyes et al. (35) & CRPCa & I & 20 & & S.C. & $\begin{array}{l}\text { Safety: } 8 / 20 \text { local erythema and pain, } \\
\text { 1/20 hypertension } \\
\text { Feasibility: } 14 / 20 \text { completed study } \\
\text { protocol } \\
\text { QOL: no change } \\
\text { Immunological: ELISPOT 7/14, DTH } \\
\text { 9/14. } \\
\text { Clinical: PSA response 6/14 }\end{array}$ \\
\hline
\end{tabular}


TABLE 1 | Continued

\begin{tabular}{|c|c|c|c|c|c|c|c|c|}
\hline $\begin{array}{l}\text { Cell Type and } \\
\text { Maturation }\end{array}$ & Antigen & Trials & Population & Phase & Pt \# & Intervention: & $\begin{array}{l}\text { Route } \pm \\
\text { adjuvant }\end{array}$ & Outcome \\
\hline & & & & & & Apoptotic cell line & & \\
\hline \multirow[t]{3}{*}{ TNF- $\alpha$, PGE-2 } & LNCaP & $\begin{array}{l}\text { Frank et al. (36) } \\
\text { NCT00289341 }\end{array}$ & $\begin{array}{l}\text { bcrCSPCa or } \\
\text { CRPCa }\end{array}$ & 1 & 24 & $\begin{array}{l}\text { Arm1: Vaccine } \\
\text { weeks } 1-7(n=12) \\
\text { Arm 2: Placebo } \\
\text { weeks 1-7, vaccine } \\
\text { weeks 8-14 }(n=12)\end{array}$ & S.C & $\begin{array}{l}\text { Safety: injection site reactions in the } \\
\text { first } 7 \text { weeks, } 11 / 12 \text { in arm } 1 \text { vs. } 2 / 12 \\
\text { arm } 2 \\
\text { Immunological: DTH response } 16 / 24 \text {, } \\
\text { T cell proliferation response } \\
\text { Clinical: } \uparrow P S A D T \text { prevaccine vs. post } \\
\text { vaccine }(P=0.003)\end{array}$ \\
\hline & & & & & & Transfected DC & & \\
\hline & PSMA protein & $\begin{array}{l}\text { Sonpavde et al. } \\
\text { (37) }\end{array}$ & mCRPCa & I & 18 & $\begin{array}{l}\text { MoDC transfected } \\
\text { with adenoviral vector } \\
\text { Ad5f35 encoding } \\
\text { inducible human } \\
\text { CD40 injected I.D. } \\
\text { then given rimiducid } \\
\text { IV } 24 \mathrm{~h} \text { later to induce } \\
\text { CD40 expression } \\
\text { on DC }\end{array}$ & I.D. & $\begin{array}{l}\text { Safety: } 18 / 18 \text { local reaction, fatigue } \\
6 / 18 \text {, myalgias } 5 / 18 \text {, anemia } 4 / 18, \\
\text { diarrhea } 4 / 18 \text {, respiratory tract } \\
\text { infection } 4 / 18, \text { hypocalcaemia } 4 / 18, \\
\text { arthralgia } 4 / 18 \\
\text { Clinical: PSA response } 1 / 18, \\
\text { Radiological: } 2 / 18\end{array}$ \\
\hline \multirow{4}{*}{$\begin{array}{l}\text { Enriched DC } \\
\text { prep }\end{array}$} & & & & & & Protein & & \\
\hline & $\begin{array}{l}\text { PA2024 (GM-CSF } \\
\text { and PAP) }\end{array}$ & Burch et al. (38) & CRPCa & I & 13 & $\begin{array}{l}\text { Two infusions of DC } \\
\text { with PAP alone and } \\
\text { then three infusions } \\
\text { of PA2024 }\end{array}$ & I.V. & $\begin{array}{l}\text { Safety: G1-2 fever } 5 / 13, \text { G1-2 } \\
\text { myalgia } 5 / 13 \text {, G1-2 fatigue } 6 / 13 \text {, G3 } \\
\text { fatigue } 1 / 13 \text {, local reactions } 4 / 13 \\
\text { Immunological: T cell proliferation 9/9, } \\
\text { Clinical: PSA response } 3 / 12\end{array}$ \\
\hline & $\begin{array}{l}\text { PA2024 (GM-CSF } \\
\text { and PAP) }\end{array}$ & Small et al. (39) & CRPCa & $|/| \mid$ & 31 & $\begin{array}{l}\text { Arm 1: Sipuleucel-T } \\
\text { Arm 2: Sipuleucel-T } \\
\text { as well KLH loaded } \\
\text { DC }(n=5)\end{array}$ & I.V. & $\begin{array}{l}\text { Safety: febrile reactions } 15 / 102, \mathrm{G} 3 \\
\text { febrile reactions } 2 / 102 \text {, myalgias } \\
2 / 31 \text {, fatigue } 1 / 31 \text {, urinary symptoms } \\
\text { 5/31 } \\
\text { Immunological: T cell proliferation } \\
\text { 10/26, 16/31 Antibody response } \\
\text { 16/31 } \\
\text { Clinical: PSA response } 3 / 31\end{array}$ \\
\hline & Mouse PAP & Fong et al. $(40,41)$ & $\mathrm{PrCa}$ & I & 21 & $\begin{array}{l}\text { Arm 1: I.V. }(n=9) \\
\text { Arm 2: I.D. }(n=6) \\
\text { Arm 3: I.L. }(n=6)\end{array}$ & I.V., I.L., I.D. & $\begin{array}{l}\text { Safety: Transfusion reactions in 2/18 } \\
\text { I.V. injections } \\
\text { Immunological: T cell proliferation } \\
\text { against mPAP } 21 / 21 \text { pts. Ag specific } \\
\text { IFN- } \gamma \text { response 0/9 I.V., 4/6 I.D., } \\
\text { 3/6 I.L. }\end{array}$ \\
\hline
\end{tabular}


TABLE 1 | Continued

\begin{tabular}{|c|c|c|c|c|c|c|c|c|}
\hline $\begin{array}{l}\text { Cell Type and } \\
\text { Maturation }\end{array}$ & Antigen & Trials & Population & Phase & Pt \# & Intervention: & $\begin{array}{l}\text { Route } \pm \\
\text { adjuvant }\end{array}$ & Outcome \\
\hline & $\begin{array}{l}\text { PA2024 (GM-CSF } \\
\text { and PAP) }\end{array}$ & $\begin{array}{l}\text { Fong et al. (12) } \\
\text { NCT00715104 }\end{array}$ & Localized PrCa & $\|$ & 42 & $\begin{array}{l}\text { Three doses } \\
\text { Neoadjuvant treated } \\
\text { prior to planned RP } \\
\text { Arm 1: 4th injection } \\
12 \text { weeks post RP } \\
\text { Arm 2: NO boost }\end{array}$ & & $\begin{array}{l}\text { Safety: fatigue, oral paresthesia } \\
\text { Immunological: } 57 \% \text { pts had a 3-fold } \\
\text { increase in tumor interface T cells }\end{array}$ \\
\hline & $\begin{array}{l}\text { PA2024 (GM-CSF } \\
\text { and PAP) }\end{array}$ & Higano et al. (13) & $\begin{array}{l}\text { Asymptomatic } \\
\text { CRPCA }\end{array}$ & III & 147 & $\begin{array}{l}\text { Arm 1: Placebo } \\
\text { Arm 2: Sipuleucel-T }\end{array}$ & I.V. & $\begin{array}{l}\text { Clinical: OS } 19 \text { vs. } 23.2 \text { months (HR } \\
\text { 1.5, Cl } 1.1-2.05, p=0.011) T T P 10 \\
\text { vs. } 11 \text { months (HR } 1.260 .95-1.58, p \\
=0.111 \text { ) }\end{array}$ \\
\hline & $\begin{array}{l}\text { PA2024 (GM-CSF } \\
\text { and PAP) }\end{array}$ & Kantoff et al. (5) & $\begin{array}{l}\text { Asymptomatic } \\
\text { CRPCA }\end{array}$ & III & 512 & $\begin{array}{l}\text { Arm 1: Sipuleucel-T } \\
\text { Arm 2: Placebo }\end{array}$ & I.V. & $\begin{array}{l}\text { Clinical: OS } 25.8 \text { vs. } 21.7 \text { months (HR } \\
0.78 \mathrm{Cl} 0.61-0.98, p=0.03 \text { ) }\end{array}$ \\
\hline & $\begin{array}{l}\text { PA2024 (GM-CSF } \\
\text { and PAP) }\end{array}$ & Beer et al. (42) & bcrCSPCa & III & 176 & $\begin{array}{l}\text { Pts with biochemical } \\
\text { recurrence after RP } \\
\text { were given 3-4 } \\
\text { months of ADT and } \\
\text { then randomized to: } \\
\text { Arm 1: Sipuleucel-T } \\
\text { Arm 2: Placebo }\end{array}$ & I.V. & $\begin{array}{l}\text { Primary: } \\
\text { Biochemical Failure PSA > 3.0: } 18 \\
\text { vs. } 15.4 \text { months HR } 0.93, p=0.73) \\
\text { Secondary: } \\
\text { PSADT: } \uparrow P S A D T 48 \%(p=0.038) \\
\text { OS }\end{array}$ \\
\hline DC & & & & & & Peptide (HLA-A2) & & \\
\hline CD1c & $\begin{array}{l}\text { PSA }_{174-183} \\
\text { PSMA }_{711-719} \\
\text { PAP }_{299-311} \\
\text { Control peptides: } \\
\text { FMP GILGFVFTL } \\
\text { KLH }\end{array}$ & Prue et al. (43) & $\begin{array}{l}\text { Asymptomatic } \\
\text { mCRPCa } \\
\text { (HLA-A2) }\end{array}$ & I & 14 & $\begin{array}{l}\text { All } 3 \text { injections of } \\
\text { CD1c: } \\
\text { Arm 1: I.D. } 1 \times 10^{6} \\
\text { Arm 2: I.D. } \\
\text { 1-5 × 10 } \\
\text { Arm 3: I.V. } 1 \times 10^{6} \\
\text { Arm 4: I.V. } 1-5 \times 10^{6}\end{array}$ & I.V. or I.D. & $\begin{array}{l}\text { Primary: } \\
\text { Safety: fever and pain } \\
\text { Feasibility: } 12 / 12 \text { underwent } \\
\text { leukapheresis and vaccination, 11/12 } \\
\text { received } 2 \text { nd vaccination } \\
\text { Secondary: } \\
\text { Immunological: DTH response 0/12, } \\
\text { ELISPOT response 0/12, Pentamer } \\
\text { positive CD8 }{ }^{+} \text {T cells 0/12 } \\
\text { Clinical: PSA response 0/12 }\end{array}$ \\
\hline
\end{tabular}


TABLE 1 | Continued

\begin{tabular}{|c|c|c|c|c|c|c|c|c|}
\hline $\begin{array}{l}\text { Cell Type and } \\
\text { Maturation }\end{array}$ & Antigen & Trials & Population & Phase & $\mathrm{Pt} \#$ & Intervention: & $\begin{array}{l}\text { Route } \pm \\
\text { adjuvant }\end{array}$ & Outcome \\
\hline \multirow[t]{2}{*}{$\begin{array}{l}\text { CD1c } \\
\text { pDC (protamine } \\
\text { and mRNA) }\end{array}$} & $\begin{array}{l}\text { NY-ESO-1 } 157-165 \\
\text { NY-ESO-1 } \\
\text { (peptivator) } \\
\text { MAGE-C2 } 336-34 \\
\text { MUC1 (peptivator) } \\
\text { KLH (control) }\end{array}$ & $\begin{array}{l}\text { Westdorp et al. } \\
\text { (44) } \\
\text { NCT02692976 }\end{array}$ & $\begin{array}{l}\text { Chemo naive } \\
\text { CRPCa (HLA-A2) }\end{array}$ & $\|$ & 21 & $\begin{array}{l}\text { Arm 1: } \mathrm{mDC} \\
\text { vaccination } \\
\text { Arm 2: } \mathrm{DDC} \\
\text { vaccination } \\
\text { Arm 3: } \mathrm{mDC} \text { and } \\
\mathrm{pDC} \text { vaccinations }\end{array}$ & I.N. & $\begin{array}{l}\text { Safety: anemia 15/21, flu like } \\
\text { symptoms 10/21, fatigue } 8 / 21 \\
\text { Immune Response: Dextramer } \\
\text { positive T cells to } \\
\text { NY-ESO-1 5/21, MAGE-C2 4/21, } \\
\text { MUC-1 2/21 } \\
\text { Antigen Specific CD8 }+ \text { T cells in DTH } \\
\text { Response: } 15 / 21 \text { pts-no difference } \\
\text { between arms } \\
\text { Clinical Response: PSA response } \\
\text { 2/21, Radiological 1/21 }\end{array}$ \\
\hline & & & & & & Combination therapy & & \\
\hline $\begin{array}{l}\text { Mature MoDC } \\
\text { (poly I:C) }\end{array}$ & Cell lysate (LNCaP) & Podrazil et al. (45) & CRPCa & $|/| \mid$ & 25 & $\begin{array}{l}7 \text { days of metronomic } \\
\text { cyclophosphamide } \\
\text { then } 2 \text { doses of } \\
\text { vaccine and then } 3 \\
\text { weekly docetaxel and } \\
\text { vaccine }\end{array}$ & $\begin{array}{l}\text { S.C. with } \\
\text { Imiquimod }\end{array}$ & $\begin{array}{l}\text { Safety: fatigue } 17 / 350 \\
\text { Immunological: Intracellular cytokine } \\
\text { response to PSA 11/23, MAGE-A1 } \\
\text { 6/23, MAGE-A2 3/23 } \\
\text { Antibody Response: PSA 6/23, Mage } \\
\text { A3 8/23 } \\
\text { Clinical: PSA response 9/23 }\end{array}$ \\
\hline $\begin{array}{l}\text { Mature MoDC } \\
\text { (cytokine cocktail) }\end{array}$ & $\begin{array}{l}\text { mRNA } \\
\text { PAP and PSA }\end{array}$ & $\begin{array}{l}\text { Kongsted et al. } \\
\text { (46) } \\
\text { NCT01446731 }\end{array}$ & CRPCa & $\|$ & 43 & $\begin{array}{l}\text { Arm 1: Docetaxel } 75 \\
\mathrm{mg} / \mathrm{m}^{2} \text { every } 3 \\
\text { weeks } \\
\text { Arm 2: Docetaxel } 75 \\
\mathrm{mg} / \mathrm{m}^{2} \text { every } 3 \\
\text { weeks DCvac twice } \\
\text { every } 3 \text { weeks for } \\
\text { cycles } 1-4 \text { then once } \\
\text { cycles } 5-10\end{array}$ & I.D. & $\begin{array}{l}\text { Primary: } \\
\text { Development of measurable } \\
\text { peripheral immune Response: } \\
\text { ELISPOT: } 9 / 18, \text { DTH: } 3 / 18 \\
\text { Secondary: } \\
\text { Safety and Toxicity: local reactions } \\
\text { and rash, Discontinuation of } \\
\text { Treatment: } 21.1 \text { vs. } 57 \% \\
\text { PSA Response: } 58 \text { vs. } 38 \%, p=0.21 \\
\text { PFS: } 5.5 \text { vs. } 5.7 \text { months }(p=0.62) \\
\text { DSS: } 21.9 \text { vs. } 25.1 \text { months }(p=0.60)\end{array}$ \\
\hline DC enriched & $\begin{array}{l}\text { PA2024 (GM-CSF } \\
\text { and PAP) }\end{array}$ & $\begin{array}{l}\text { Twardowski et al. } \\
\text { (47) }\end{array}$ & mCRPCa & $\|$ & 51 & $\begin{array}{l}\text { Arm A: sipuleucel-T } \\
\text { alone }(n=24) \\
\text { Arm B: RT to single } \\
\text { metastatic site } \\
\text { followed by } \\
\text { sipuleucel-T }(n=25)\end{array}$ & I.V. & $\begin{array}{l}\text { Primary: } \\
\text { Safety: G2 fatigue } 1 / 24 \text { vs. } 3 / 25 \\
\text { Secondary: } \\
\text { ELISPOT IFNy } \uparrow \text { in Arm A compared to } \\
\text { B ( } p=0.028) . \\
\text { PFS } 2.46 \text { vs. } 3.65 \text { months ( } p=0.06)\end{array}$ \\
\hline DC enriched & $\begin{array}{l}\text { PA2024 (GM-CSF } \\
\text { and PAP) }\end{array}$ & $\begin{array}{l}\text { Antonarkis et al. } \\
\text { (48) } \\
\text { NCT01431391 }\end{array}$ & bcrCSPCa & $\|$ & & $\begin{array}{l}\text { Arm A: Sipuleucel-T } \\
\text { followed by ADT } 2 \\
\text { weeks after } \\
\text { Arm B: ADT for } 12 \\
\text { weeks } \\
\text { then Sipuleucel-T }\end{array}$ & I.V. & $\begin{array}{l}\text { Primary: } \\
\text { ELISPOT-approx. 2-fold higher for } \\
\text { Arm A than Arm B ( } p=0.001) \\
\text { Secondary: } \\
\text { Time to PSA progression } 21.8 \text { vs. } \\
22.6(p=0.357)\end{array}$ \\
\hline
\end{tabular}


TABLE 1 | Continued

\begin{tabular}{|c|c|c|c|c|c|c|c|c|}
\hline $\begin{array}{l}\text { Cell Type and } \\
\text { Maturation }\end{array}$ & Antigen & Trials & Population & Phase & Pt\# & Intervention: & $\begin{array}{l}\text { Route } \pm \\
\text { adjuvant }\end{array}$ & Outcome \\
\hline DC enriched & $\begin{array}{l}\text { PA2024 (GM-CSF } \\
\text { and PAP) }\end{array}$ & Scholz et al. (49) & $\begin{array}{l}\text { mCRPCa } \\
\text { NCT01832870 }\end{array}$ & 1 & 9 & $\begin{array}{l}\text { Ipilimumab and } \\
\text { Sipuleucel-T }\end{array}$ & I.V. & $\begin{array}{l}\text { Safety: well tolerated only } 1 \mathrm{G} 1 \text { rash } \\
\text { Immunological: increase in humeral } \\
\text { immunity against PA2024 and PAP }\end{array}$ \\
\hline Poly I:C & Cell lysate (LNCaP) & $\begin{array}{l}\text { Fucikova et al. (50) } \\
\text { EudraCT 2009- } \\
017259-91\end{array}$ & bcrCSPCa & $1 / I 1$ & 27 & $\begin{array}{l}1 \text { week of } \\
\text { metronomic } \\
\text { cyclophosphamide } \\
\text { then DC vaccine } \\
\text { every } 2-6 \text { weeks for } \\
\text { approx. up to all } \\
\text { manufactured doses } \\
\text { on average } 12\end{array}$ & $\begin{array}{l}\text { S.C. with } \\
\text { Imiquimod }\end{array}$ & $\begin{array}{l}\text { Immunological: IFN- } \gamma \text { specific T cells } \\
\text { to PSA 12/27, MAGE 6/27 } \\
\text { Antibody Response to: PSA 9/27, } \\
\text { MAGE 9/27 } \\
\text { Clinical: increase in PSADT 22/25 }\end{array}$ \\
\hline DC enriched & $\begin{array}{l}\text { PA2024 (GM-CSF } \\
\text { and PAP) }\end{array}$ & $\begin{array}{l}\text { Small et al. (51) } \\
\text { NCT01487863 }\end{array}$ & mCRPCA & $\|$ & 69 & $\begin{array}{l}\text { Arm A: concurrent } \\
\text { Sipuleucel-T and } \\
\text { abiraterone } \\
\text { Arm B: Sipuleucel-T } \\
\text { for } 10 \text { weeks } \\
\text { then abiraterone }\end{array}$ & I.V. & No difference in immune response \\
\hline DC enriched & $\begin{array}{l}\text { PA2024 (GM-CSF } \\
\text { and PAP) }\end{array}$ & $\begin{array}{l}\text { Rini et al. (52) } \\
\text { NCT00027599 }\end{array}$ & bcrCSPCa & 1 & 22 & $\begin{array}{l}\text { Sipuleucel-T and } \\
\text { bevacizumab }\end{array}$ & I.V. & $\begin{array}{l}\text { Clinical: } \uparrow \text { PSADT } 6.9 \text { vs. } 12.7 \text { months } \\
\text { post treatment }(p=0.01)\end{array}$ \\
\hline DC enriched & $\begin{array}{l}\text { PA2024 (GM-CSF } \\
\text { and PAP) }\end{array}$ & Jha et al. (53) & mCRPCa & $\|$ & 46 & $\begin{array}{l}\text { Arm A: Sipuleucel-T } \\
+ \text { indoximod } \\
\text { Arm B: Sipuleucel-T }\end{array}$ & I.V. & $\begin{array}{l}\text { Clinical: PSA progression no diff PFS } \\
10.3 \text { vs. } 4.1 \text { months }(p=0.011)\end{array}$ \\
\hline
\end{tabular}

Cytokine cocktail (TNF- $\alpha$, IL-1ß, IL-6, PGE2), mCRPCa, metastatic castrate resistant prostate cancer; bcrCSPCa, biochemical recurrence of castrate sensitive prostate cancer; DTH, delayed hypersensitivity, antigen specific response reported; PSADT, PSA doubling time; I.V., intravenous; I.N., intranodal; I.D., intradermal; S.C., subcutaneous. 
$4 \%$ of I.D., injected DC, migrate to local lymph nodes but those that do activate $\mathrm{CD}^{+} \mathrm{T}$ cells in a melanoma model, thus overcoming microenvironment of melanoma (17). There have been several clinic trials in PCa with MoDC (Table 1). They vary in their mode of antigen delivery (protein, peptide, apoptotic tumor cells, cell lysate from tumor cell lines or mRNA) (Table 1, Figure 1), whether the MoDC are immature or mature and if matured what activation agent was used (Table 1, Figure 1). All these nuances have a profound impact on efficacy and applicability thus it is worth exploring these differences in more detail.

\section{Mature vs. Immature DC}

Firstly, early trials used immature MoDC and as one would expect, immature MoDC have reduced expression of activation markers, reduced ability to stimulate T cells $(54,55)$ and reduced ability to migrate (55). A meta-analysis that extracted individual patient data from 10 clinical trials of $\mathrm{DC}$ vaccines in $\mathrm{PCa}$ confirmed that immature MoDC preparations had less clinical benefit than mature MoDC (56). In melanoma patients immature and mature MoDC preps were compared head-to-head, again immature MoDC were less effective (57).

Different maturation agents have been used (Table 1, Figure 1) and at least in vitro they activate different gene expression profiles in the MoDC which in turn causes differing $\mathrm{T}$ cell responses (58). Broadly, maturation agents haven been chosen that are GMP grade, induce activation markers and produce MoDC that stimulate $\mathrm{T}$ cells toward a type 1 helper $\mathrm{T}$ cell response. Human cytokine cocktail, consisting of TNF$\alpha$, IL-1 $\beta$, IL-6, PGE2, has been most frequently used in MoDC trials (Table 1). This mix produces mature MoDC with a superior ability to stimulate $\mathrm{T}$ cells than immature MoDC (59) and improved migratory capacity to mobilize DC to lymph nodes where they can prime $\mathrm{T}$ cells (60). However, there is data that these MoDC preferentially recruit T-regs, thus, potentially dampening any immune response initiated $(61,62)$.

Polyinosinic-polycytidylic acid [poly(I:C)] is a synthetic analog of dsRNA and is a clinical grade TLR3 agonist that matures DC (63). These DC, unlike those produced by the cytokine cocktail, produced high levels IL-12 (64) which directs a Th1 type $\mathrm{T}$ cell response. In vitro experiments suggest better antigen specific $\mathrm{T}$ cell proliferation and less $\mathrm{T}$ reg development $(60,62)$. In clinical trials Poly I:C matured MoDC vaccines are reportedly well-tolerated producing immunological and clinical responses (50). However, there are no clinical trials that compare Poly (I:C) matured MoDC with cytokine cocktail matured MoDC directly.

A third combination of CD40L with IFN- $\gamma$ has shown promise, similarly increasing IL-12 cytokine production (65). Whilst this combination has not been used in PCa, CD40L has been used in other cancer vaccines. In resected metastatic colorectal cancer, a small, randomized phase I DC vaccine trial randomized tumor lysate pulsed MoDC cultured with or without recombinant CD40L. CD40L induced CD86 and CD83 expression on DC but in this small study of only 26 patients, CD40L did not improve anti-tumor specific $\mathrm{T}$ cell proliferation, IFN $\gamma$ ELISPOT response, DTH response or relapse free survival (66). Similarly, in melanoma patients where CD40L was compared to cytokine cocktail, no difference was found in immunological response (67).

There are numerous reasons why we do not see clinical effect of different DC maturation strategies despite promising preclinical data. One is that small gains in maturation state in vitro maybe overpowered by the immune environment in vivo. One strategy that aims to control this is the use of viral vectors to genetically modify DC. In PCa Sonpavde et al. (37) showed feasibility, safety, and the development of a peripheral immune response when DC were transfected with inducible human CD40 (37). In this trial an adenovirus vector was used to transfect DC with human CD40 that had its cytoplasmic domain fused to ligand-binding domains and a membrane-targeting sequence to allow CD40 to be regulated by lipid-permeable dimerizing drugs, in this case rimiducid (68). This allows control over the timing of CD40 expression. DC vaccine was given and $24 \mathrm{~h}$ after injection, when DC have migrated to the lymph node and are in close contact with $\mathrm{T}$ cells, rimiducid is given to activate CD40. In this phase 1 study, $86 \%$ of patients had stable disease, with just $10 \%$ with a partial response (37). In PCa PSA kinetics reported as PSA doubling time (PSADT) are an indicator of prognosis with a shorter PSADT indicating a worse prognosis (69). In this study, $53 \%$ of patients had an increase in their PSADT, a surrogate marker for improved clinical outcome. This proof of concept shows that we can co-ordinate both timing and activation state of DCs to improve clinical outcomes.

\section{Form of Antigen}

Another variable amongst the different DC vaccination strategy is the type and form of antigen loaded onto DC.

\section{Peptide or Protein}

The most common source of antigen is protein. Early DC vaccines use short peptide sequences unique to tumor associated antigens that are known to bind to specific HLA subtypes, mainly HLA-A2. Short peptides are easy to make and are quickly presented on MHC class I by DC when added to culture media. However, they have several disadvantages. They must be suitable for that patient's HLA subtype or else, as they will not be presented, and immune responses will be limited (18). Whilst several vaccines have been trialed selecting patients of HLAA2 subtype this excludes at least half of eligible patients and represents a higher percentage of the Caucasian population than other ethnics backgrounds (70). Additionally, short peptides that target a CD8 ${ }^{+} \mathrm{T}$ cell response won't harness $\mathrm{CD} 4^{+} \mathrm{T}$ cell help limiting $\mathrm{T}$ cell expansion, cytotoxicity, and memory (71). MHC Class II molecules are more variable than MHC class I and thus designing short peptides to target them as well as MHC class I to cover large proportions of the populations becomes complicated and difficult to standardize.

The limitations of peptide loading can be overcome by administering whole protein for DC to uptake and process. Recombinant protein is easy to obtain and can be added directly to culture media. The advantage of administering whole protein is that after DC processing, multiple peptides are available that bind both MHC class I and II and multiple HLA types. 
The disadvantages are that these proteins may not cover the potentially more immunogenic mutations found in the tumor and reagents to monitor peptide specific responses may not be available. Also, by focusing on one to four proteins, this leaves open the possibility of immune escape as tumors down regulate expression of these proteins. In the case of $\mathrm{PCa}$, most proteins used in clinical trial including PSA, PSMA, and PAP are overexpressed self-antigen and thus have issue with selftolerance.

\section{Tumor Cells}

Cell lysate has the benefit of presenting a multitude of tumor protein both known and unknown, as well as mutated protein found in the tumor. These mutated proteins give rise to neoantigens that overcome the problem of self-tolerance and thus are more immunogenic. A common way to produce cell lysate is to freeze/thaw cells for several cycles producing necrotic cell death. This process leaves cell membrane fragments, RNA and DNA in the lysate which provide danger signals promoting DC maturation (72). Once produced cell lysate is added to culture media at ratios of 5:1 (45) and up to 1:1. This requires access to a large amount of tumor material, which, particularly in the setting of CRPCa, is difficult. This has led to the use of allogeneic cell lines as surrogate tumor tissue in four clinical trials in PCa $(25,35,45,50)$ (Table 1). Two of these trials combine treatment with metronomic cyclophosphamide for 7 days prior to DC vaccination $(45,50)$. These trials show that the use of tumor lysate is safe and produces a tumor-specific immunological response as well as increasing PSADT $(36,50)$.

Allogeneic apoptotic tumor cells (36) have similar capacity as cell lysate to mature DC and prime $\mathrm{T}$ cells to produce an antigen specific immune response (73). Apoptotic tumor cells are effectively phagocytosed by immature DC (74-76) and their tumor antigens are preferentially cross-presented to $\mathrm{CD} 8^{+} \mathrm{T}$ cells. A melanoma mouse models suggest that apoptotic tumor cells induces more IL-12 secretion by DC than cell lysate (73). In patients with CLL in vivo studies support this finding show that apoptotic tumor cell loaded MoDC produce better T cell proliferation, higher frequency of IFN $\gamma$ producing $\mathrm{T}$ cells via ELISPOT and by PCR less mRNA for the Th2 cytokines IL-4 and IL-10 than cell lysate and mRNA pulsed MoDC (77).

Other forms of presenting tumor antigen to DC include producing hybrids of DC and tumor cells fused using polyethylene glycol (PEG). These made in vitro using PCa cell lines ONYCAP23, P4E6, and $\mathrm{LNCaP}$ and MoDC, can produce a tumor cell-specific immune response (78). Conceptually, by fusing the cells, endogenous tumor antigens have better access to MHC class I molecules. Several early phase I/II clinical trials in melanoma, glioma, renal cell carcinoma, breast cancer demonstrate that this is feasible, safe, and produces clinical responses (79).

Exomes provide an acellular source of tumor antigen. Exomes are nano-sized particles originating from multivesicular bodies. They can be isolated from the blood and urine of PCa patients (80) providing a source of current antigenic material that is often difficult to obtain in mCRPCa and facilitating a mechanism for a personalized vaccine. Exomes have long been known to have immunosuppressive properties (81), suppressing T cell and NK cell function in the tumor microenvironment. In direct contrast to this, when exosomes activate DC which activate tumor specific T cells as effectively as cell lysate $(81,82)$. This creates a promising pathway for future autologous prostate cancer tumor loaded DC vaccines.

\section{Messenger RNA}

Finally, mRNA provides another source of antigen (74), which DC can take up and translate into protein for presentation on MHC class I. mRNA has the advantage that it can be prepared in sufficient quantity from a small tumor sample and thus it also allows for the ability to produce personalized vaccines. There are four ways of administering mRNA to the DC (a) passive, (b) liposome mediated, (c) electroporation, and (d) viral vector mediated. By far the most common way is electroporation. This has been done in a phase II trial in PCa that compares mRNA loaded MoDC in combination with docetaxel to docetaxel alone (46) (Table 1). Whilst it was deemed to be safe with the only toxicity identified as related to vaccine local reactions and rash, there was a much higher discontinuation of treatment in the vaccine arm- -57 vs. $21 \%$. The vaccine arm required much more frequent visits, however, as reasons for discontinuation where not reported, additionally toxicity cannot be excluded.

\section{Route of Administration}

MoDC vaccines have been administered in multiple different routes including intravenous (I.V.), intranodal (I.N.), intralymphatic (I.L), intradermal (I.D.), and subcutaneous (S.C). In a meta-analysis that pooled individual data from 84 patients, routes that allow migration to local lymph nodes i.e., I.D./I.L./I.N./S.C lead to better clinical response compared to the I.V. route (OR 3.2, 95\% CI 1.1-9.0) (56). Fong et al. (41) showed similar findings using density enriched DC with a better cytokine profile seen with I.D. and I.L. route compared to I.V. with a trend to more transfusion reactions in the I.V. group.

Despite the variability in preparation as a whole these trials (Table 1) show that MoDC vaccinations in $\mathrm{PCa}$ are safe, produce a cellular immune response and a clinical response with a fall in PSA seen in up 27\% $(9 / 33)(18,50,83)$. However, it is important to note that an immunological response does not necessarily correlate with outcome $(45,46,50)$ and often peripheral immune responses when detected are not sustained (46). Thus, the outcomes measured may not be clinically significant. Surrogate endpoints of reduction in PSA and difference in PFS may also not correlated with OS, as seen with Sipuleucel-T (5). Thus, despite a multitude of early trials we really need a Phase III trial of MoDC that looks at OS to determine clinical significance. The results of NCT02111577, a double blinded Phase III trial of MoDC loaded with apoptotic LNCaP cells added to standard chemotherapy for men with mCRPCa which has completed recruitment with 1,182 patients, should provide us with some clearer answers.

However, even without the results of this trial there are a number of reasons why MoDC preparations may not be the optimal approach. Monocytes are known to be dysfunctional in advanced cancer including in PCa. Most preclinical information on MoDC has been collected using healthy donor PBMC. 
However, when we compare MoDC prepared from healthy donors to those from patients with advanced cancer, patient MoDC are less efficient at phagocytosis, produce less IL-12 and express lower levels of the activation marker CD80 (84). In study of 24 patients with localized $\mathrm{PCa}, \mathrm{MoDC}$ failed to upregulate CD80, CD83, and CCR7 after maturation with human cytokine cocktail, although for most patients, but not all, this was restored after surgery (85). In contrast two studies of only five patients each did show that MoDC from PCa patients were as good as healthy donors $(32,86)$.

The biggest issue with MoDC is that even from healthy donor PBMC, they do not perform as well as blood-derived DC; they do not stimulate T cells as well $(54,87)$, migrate as well (88) or have as much clinical efficacy (56). Thus, despite ease of production, MoDC vaccinations are unlikely to improve on the effectiveness of Sipuleucel-T.

\section{Blood Derived DC Vaccines}

Advances in efficiency of isolation protocols allow the use of blood DC as an alternative to MoDC or DC enriched preparations (Figure 1). Prue et al. (43) in a phase I trial showed that it was feasible to isolate $\mathrm{CD} 1 \mathrm{c}^{+} \mathrm{DC}$ from CRPCa patients via magnetic separation and vaccination, was welltolerated with fever and pain the most common toxicity (43). More recently, in a phase II RCT Westdorp compared the efficacy of matured myeloid (m)DC vs. plasmacytoid (p)DC vs. combination of $\mathrm{mDC}$ and $\mathrm{pDC}$ (44). Again, this showed that blood derived DC were safe and induced an immune response, with a trend to a better response with $\mathrm{mDC}$ alone. These technical advances in isolating DC as a pure population and, as demonstrated by Westdorp et al. (44) isolating specific DC subsets and utilize the underlying specialization of human DC to take up antigen allows us to direct the immune response in a particular direction.

\section{Targeting DC Subsets}

Blood DC can initially be divided into two main populations: $\mathrm{pDC}$ and $\mathrm{mDC}$. Human pDC are identified by their surface expression of $\mathrm{CD} 304^{+}$. They are characterized by their ability to produce large amounts of Type 1 interferon in response to foreign nucleic acids i.e., in response to viral infections (89). In humans, they orchestrate antigen specific $\mathrm{CD} 4^{+} \mathrm{T}$ cell responses as well as cross present antigen to create $\mathrm{CD}^{+}{ }^{+} \mathrm{T}$ cell responses $(90,91)$. $\mathrm{mDC}$, divided based on phenotype and function into five subsets, the main being $\mathrm{CDC} 1$ and $\mathrm{CDC} 2$ (92). cDC1, characterized by CD141 expression, have the ability to cross present exogenous antigen to prime $\mathrm{CD} 8^{+} \mathrm{T}$ cell response, direct a type 1 helper $\mathrm{T}$ cell responses and through the production of IL-12, and direct an NK response (93). cDC2, are characterized by $\mathrm{CD}_{1} \mathrm{c}^{+}$expression, have a more diverse function and are able to simulate Th1, Th2, Th17, and $\mathrm{CD}^{+} \mathrm{T}$ cell responses (93). As suggested by Westdorp et al. (44) the mix of DC we use for a vaccine will affect efficacy (44). Whether we use a mixed preparation of mononuclear cells, DC, T cells, B cells, and NK cells such as in Sipuleucel-T (94), MoDC or a pure DC subset will change the direction of the $\mathrm{T}$ cell response. Traditionally we have looked at $\mathrm{mDC}$ particularly $\mathrm{CDC} 1$, as key to orchestrating a cytotoxic immune response. They are most adept at priming $\mathrm{CD} 8^{+} \mathrm{T}$ cells because they have adapted their intracellular machinery to be extremely efficient at cross presentation of antigen (95). Whilst they have been the focus of much vaccine development, as we learn more about the need for Thelper support to create effective $\mathrm{CD} 8^{+} \mathrm{T}$ cell response $(96,97)$ an approach that utilizes both $\mathrm{CDC} 1$ to activate $\mathrm{CD} 8^{+} \mathrm{T}$ cells and $\mathrm{CDC} 2$ to activate $\mathrm{CD} 4^{+} \mathrm{T}$ cells would give a more robust anti-tumor immune response (98). A novel way of targeting these naturally occurring DC is to target DC in situ. Emerging technologies such as antibody-antigen conjugates and virus codelivery systems not only provide a DC therapy that improve delivery they also improve efficacy.

\section{IN SITU DC TARGETING}

\section{Antibody Directed Antigen-Uptake}

One way to target DC is to couple antigen to antibodies that bind endocytic cell surface molecules unique to DC. Preclinical data in mouse models show that delivering antigen in this way increases the efficiency of antigen presentation. Coupling OVA to the rat anti-mouse DEC-205 antibody (clone: NLDC-145) lead to a $>100$-fold increase in efficiency of DC antigen presented to mouse $\mathrm{CD}^{+}$and $\mathrm{CD}^{+} \mathrm{T}$ cells (99). Thus, targeting antigen directly to DC with antibody increases antigen presentation and in both in vivo mouse models and in vitro human models this leads to improved T cell response (100-102). However, in the absence of a maturation signal to the DC or indeed as a consequence of the function of the molecule targeted, this $\mathrm{T}$ cell response did not persist and in fact peripheral tolerance was induced (99). In contrast, in the presence of adjuvant such as anti-CD40 a strong memory response is formed after injection with OVA conjugated DEC-205, with CTL responses detectable up to 90 days after a single immunization (100). This need for a second "danger" signal to direct the immune system to form an inflammatory rather than tolerogenic response to the targeted antigen is not unique to DEC-205 antibodies but common to many surface antibody targets studied to date $(99,100,103,104)$. However, the selection of adjuvant in a clinical setting will need careful consideration to minimize side effects.

Despite the need for adjuvant, the safety and ease of delivery of in vivo DC targeting has been demonstrated in a phase I clinical trial of CDX-1401, a fully human anti-DEC-205 (CD205) $\mathrm{mAb}$ (3G9) genetically fused to the full-length NY-ESO-1 protein. The vaccine was used in combination with resiquimod (TLR7/8 agonists) and poly-(I:C) as adjuvants. It was well-tolerated in the 45 patients who entered the study and, induced a cellular immune response in 56\% and humoral immune response in $79 \%$ of cases. Thirteen patients developed stable disease and 2 a partial response (105). This demonstrates that using antibody to target antigen to DC is safe and feasible and can induce an immune response in humans.

While safety has been demonstrated, reports on trials in ovarian cancer and acute myeloid leukemia (AML) are awaited. There remains the question of choice of molecule to target as targeting DEC-205 which naturally trends toward tolerance 
may be superceeded. Clec9a (CD370) is another endocytic surface marker with a much narrower expression profile. Whilst DEC-205 is highly expressed on $\mathrm{cDC1}$ it is also expressed on monocytes, B lymphocytes and low levels on T cells and NK cells. In contrast, Clec-9A expression is limited to $\mathrm{CDC1}$, which is the DC subset known for their ability to cross present antigen and elicit a $\mathrm{CD}^{+}$cytotoxic $\mathrm{T}$ cell response, ideal for a tumor vaccine. The other interesting ability of Clec9a is its ability to drive a memory immune response without adjuvant, however, in mice tumor models, adjuvant is still required (106). Whilst this looks like a promising target, it has been demonstrated that the $\mathrm{CDC1}$ population, which is targeted by Clec9a is reduced in PCa (107) and is less responsive to activation with poly (I:C). This suggests underlying functional impairment and testing these treatments in a PCa tumor model is awaited.

Antibody-directed antigen uptake demonstrates that DC can be loaded "in vivo" (105), is safe and produces an immune response. However, antibodies are limited by the amount of antigen that they can deliver through coupling protein to antibody before the latter's ability to bind and be endocytosed is impaired. This has led to the development of co-delivery systems.

\section{Co-delivery Systems}

Co-delivery systems have two advantages, they allow the co-administration of adjuvant with antigen and can deliver multiple antigens. Some co-delivery systems are easy to adapt to different antigen make ups thus allowing personalized vaccine with "neoantigens' matched to each patient. There are two main vehicles studied: modified viral vectors and nanoparticles. Viral vectors include the filamentous bacteriophage antigen display system and modified adenovirus. The filamentous bacteriophage system is based on a nonpathogenic prokaryotic virus which can be engineered to express exogenous peptides as fusions to viral capsid proteins $(108,109)$. The bacteriophage is the adjuvant and in a mouse model it has been manipulated to express both mouse DEC-205 and OVA. In this system it produces an enhanced $\mathrm{T}$ cell response compared to injection with OVA: DEC-205 antibody conjugate (108). Similarly, a model where attenuated adenovirus was manipulated to express OVA and anti-mouse DEC-205 (110), produced a memory CD8 $\mathrm{T}$ cell response. Whilst this shows promise in pre-clinical models, translation to humans is yet to come.

\section{Nanoparticles}

Nanoparticles perhaps are closer to translation, in particular Poly(DL-lactide-co-glycolide (PLGA), a biodegradable slowrelease polymer that is FDA approved to encapsulate drugs, can be adapted to encapsulate antigen and adjuvant (111). Due to their size nanoparticles readily taken up by DC (112) and in vitro studies show human DC take up peptide more efficiently if it is delivered inside a PLGA nanoparticle rather than soluble form (113). Nanoparticles not only direct peptide to the DC but also protect peptide from degradation, thus increasing the length of time to which DC are exposed to peptide. PLGA delivery of peptide induced T cells with a much greater CTL response than peptide loaded DC both in vitro
(113) and in vivo $(113,114)$. Nanoparticle delivery has been tested in a mouse models of prostate cancer with the mouse prostate tumor antigen, six-transmembrane epithelial antigen of the prostate (mSTEAP). In this model, a single dose of mSTEAP on PLGA nanoparticles was compared to mSTEAP peptide plus adjuvant. The nanoparticle bound mSTEAP reduced both growth of TRAMP-C2 tumor cells in C57BL/6 mice and increased OS of the mice compared to peptide combined with adjuvant (114). Thus, in a PCa model, nanoparticles were more effective than a peptide vaccine. It is important to note though that comparison to DC vaccination strategies, antibody directed antigen uptake or other novel vaccination strategies remains to be assessed.

Nanoparticles have been used as a co-delivery system for antibody directed antigen uptake. Nanoparticles coated in antiDEC-205, anti-CD40, and anti-CD11c antibodies to deliver antigen and adjuvant direct to DC all lead to increased CD8 and CD4 T cell proliferation and cytotoxicity in vitro and in vivo above non-targeted nanoparticles. CD40 targeted nanoparticles improved antigen specific $\mathrm{T}$ cell proliferation in the draining LN above other target receptors, and also cytotoxicity against target cells (115). In a mouse tumor model, CD40 nanoparticles containing OVA improved OS of B16-OVA inoculated mice compared to isotype control (116).

Whilst these emerging technology show promise in improving deliverability and efficacy of a DC based vaccine, they are yet to be translated into clinical trials in prostate cancer.

\section{Overcoming Tumor Escape}

If we are to successfully translate in situ targeting of DC, clinical benefit will not occur without understanding what drives the immunosuppressive microenvironment of PCa.

\section{Improving Antigen Processing Within Tumor Cells}

PCa evades detection of the immune system by failing to display tumor peptide in MHC class I complexes on their cell surface. This is crucial to consider in the setting of DC vaccine as cytotoxic $\mathrm{T}$ cells primed by a $\mathrm{DC}$ vaccine will not be able to kill tumor cells without the presence of MHC Class I complex on tumor cells. In primary castrate sensitive prostate cancer (CSPCa) MHC class I was downregulated in 74\% (311/419) and $\beta 2 \mathrm{M} 25 \%$ (117). In another study of 58 primary CSPC, defects in MHC class I were less common with loss of staining only in $5 \%$ of cases but heterogenous staining in $62 \%$ (117). This study also looked at the components of the antigen processing machinery within the tumor cells and demonstrated that loss or downregulation was frequent (118). Thus, treatment strategies that increase MHC Class I expression on tumor cells are candidates for combination therapies that may improve efficacy of DC vaccines. Histone deacetylase inhibitors have been assessed to reverse histone acetylation of the TAP1 promotor and, Trichostatin A, has been shown to upregulated MHC-class 1 and $\beta 2$-microglobulin in LNCaP cells. Traditional anti-PCa therapies such as docetaxel and radiation also increase all components of antigen-processing machinery in the PC cell line, LNCaP $(119,120)$ and therefore are beneficial combination strategies for DC vaccines. A phase II trial that combined MoDC vaccine with 
docetaxel showed a trend toward improvement in disease specific survival (DSS) (46), and results of the first phase III trial, NCT NCT02111577 that combines docetaxel and DC vaccine therapy are eagerly awaited.

\section{Improving T Cell Function}

A robust $\mathrm{T}$ cell response is essential for any effective DC vaccine. Thus, it is essential to understand any underlying dysfunction of the $\mathrm{T}$ cell repertoire in PCa. We know there are a paucity of $\mathrm{T}$ cells (121) in PCa and those present are less proliferative (122), more immunosuppressive (123) with a high proportion of T-regs $(122,123)$. Data from the NCT00715014 trial of neoadjuvant Sipuleucel-T shows that DC vaccination does lead to increased recruitment of $\mathrm{T}$ cells including $\mathrm{CD}^{+}, \mathrm{CD}^{+}$, and T-regs into the tumor (12). Comparing pre vaccination biopsies to post vaccination resection specimens, $\mathrm{T}$ cells had increased TCR sequence diversity in the resected prostate suggesting that Sipuleucel-T recruits $\mathrm{T}$ cells to the prostate (124) rather than reactivating those already in situ. Gene expression profiling showed an increase in Th1 associated genes and upregulation of immune checkpoint inhibitors including CTLA-4 and TIGIT (125). This raises the question of how long does the immune response last and whether combining with check point inhibitors will improve outcomes.

While monotherapy with both ipilimumab (anti-CTLA4) and PD-1 inhibitors have proved disappointing (2, 3, 126), recent long term follow of ipilimumab shows that despite low response rates those that do respond have enduring responses (127). The key will be to improve response rates and early data suggests that adding DC vaccination to immunotherapy may do just that. In a small study of nine men with mCRPCa treated with Sipuleucel-T and escalating doses of ipilimumab showed that IgG and IgM levels against PA2024 and PAP increased significantly after ipilipumab (49). A subsequent trial to look at immediate vs. delayed CTLA4 blockade (NCT01804465) has recruited and is in the follow up stage. PD-1 inhibitors have less severe immune toxicity than anti-CTLA4 antibodies, and thus are a more tolerable combination strategy. Pembrolizumab has been used in combination with a DNA vaccine in PCa and it was found that concurrent rather than sequential treatment improved PSA response (128). We look to the results of NCT03024216 to determine whether atezolizumab (anti-PD-L1) improves the efficacy of Sipuleucel-T.

Another strategy is to focus on depleting T-regs. In mouse models of PCa low dose cyclophosphamide caused transient depletion of T-regs and increased DC maturation markers and augmented anti-tumor immune response (129). In humans, metronomic oral cyclophosphamide was used in combination with a MoDC vaccine (50), and also prior to MoDC vaccine used in combination with docetaxel chemotherapy (45). In both instances it was well-tolerated. Another mechanism to reduce T-regs is to use IDO inhibitors to block the production of IDO-expressing DCs that drive $\mathrm{T}$ cells to $\mathrm{T}$ regs and activate existing $\mathrm{T}$ regs. Indoximod, an IDO inhibitor administered after Sipuelucel-T therapy was found to be well-tolerated and improved PFS from 4.1 to $10.3(p=$ 0.011) (53).

\section{Over-coming Myeloid Derived Suppressor Cells}

Myeloid cells play a large role in creating the tumor microenvironment of PCa. The presence of M2 macrophages in the tumor microenvironment is an indicator of poor prognosis (130-133). PCa cells recruit monocytes and polarize them to an M2 macrophage phenotype which then helps increase PCa cells migratory capacity, proliferation, survival and invasion $(130,134,135)$ creating a symbiotic relationship. Interestingly, a reduction in MDSC predicts response (46) to mRNA loaded MoDC vaccination and tumor cell vaccine in combination with ipilimumab (136). In mice models of lung cancer MDSC reduce the activity of NK cells and $\mathrm{T}$ cells, thus, they will dampen any immune response developed by a DC vaccine. Novel combination strategies that further reduce MDSC may improve vaccination responses. Interestingly in a breast cancer tumor model docetaxel repolarized MDSC toward an M1-like phenotype further supporting the use of docetaxel as a combination for vaccination (137).

\section{Timing and Interactions of Other Therapies}

It has long been proposed that the best time to treat with a DC vaccine is when tumor burden is low either at diagnosis or remission. This hypothesis is supported by trials that low burden of disease predicts for good response (138). Another issue is the effect of treatment on the immune system's ability to create an immune response. In the instance of $\mathrm{PCa}$, androgen deprivation therapy (ADT) is given throughout the entire treatment course. ADT enhances $\mathrm{T}$ cell responses. In a mouse model, after androgen withdrawal the biggest difference in $\mathrm{CD}^{+} \mathrm{T}$ cells was in IFN $\gamma$ signaling pathway and CD4 T helper differentiation (139). In patients in CSPCa this was also the case (140). However, we also know that these responses diminish with time, perhaps due to a disproportionate increase in T-regs (141). In a mouse model depleting T-regs with a CTLA-4 depleting antibody significantly improved OS when combined with ADT (142). The phase II STAND study assesses this in patients and showed that better immune responses were stimulated when a DC vaccine was given before initiation of $\mathrm{ADT}$ rather than after (48). Thus, the best timing for a DC vaccine maybe at biochemical recurrence when tumor burden is low and ADT has not been given.

\section{CONCLUSION}

DC vaccination strategies have been shown to be safe and improve OS. Yet they are still rarely used in clinical practice. Our understanding of antigen loading DC, antigen presentation, induction of $\mathrm{T}$ cell responses, extrinsic driving of cytotoxic responses provides multiple opportunities to improve vaccine strategy design. Here we show that emerging technologies present options for targeting DC in situ thus improving deliverability. Secondly, novel combination strategies prove promising to help improve on duration of $\mathrm{T}$ cell response. 
That DC vaccines reach their potential in stimulating effective clinical responses relies on assessing what we have learned, how we adapt trials and looking for long term, durable (or sustainable) outcomes.

\section{AUTHOR CONTRIBUTIONS}

SS: writing and figures. $\mathrm{XJ}, \mathrm{LH}$ and GC: reviewed. SS and GC: concept. All authors

\section{REFERENCES}

1. Antonarakis ES, Piulats JM, Gross-Goupil M, Goh J, Ojamaa K, Hoimes CJ, et al. Pembrolizumab for treatment-refractory metastatic castration-resistant prostate cancer: multicohort, open-label phase II KEYNOTE-199 study. J Clin Oncol. (2020) 38:395-405. doi: 10.1200/JCO.19.01638

2. Beer TM, Kwon ED, Drake CG, Fizazi K, Logothetis C, Gravis G, et al. Double-blind, phase III trial of ipilimumab versus placebo in asymptomatic or minimally symptomatic patients with metastatic chemotherapy-naive castration-resistant prostate cancer. J Clin Oncol. (2017) 35:40-7. doi: 10.1200/JCO.2016.69.1584

3. Kwon ED, Drake CG, Scher HI, Fizazi K, Bossi A, van den Eertwegh AJ, et al. Ipilimumab versus placebo after radiotherapy in patients with metastatic castration-resistant prostate cancer that had progressed after docetaxel chemotherapy (CA184-043): a multicentre, randomised, double-blind, phase 3 trial. Lancet Oncol. (2014) 15:700-12. doi: 10.1016/S1470-2045(14)70189-5

4. Hart D. The delivery of effective therapeutic cancer vaccination. Asian $J$ Androl. (2011) 13:183-4. doi: 10.1038/aja.2010.146

5. Kantoff PW, Higano CS, Shore ND, Berger ER, Small EJ, Penson DF, et al. Sipuleucel-T immunotherapy for castration-resistant prostate cancer. $\mathrm{N} \mathrm{Engl}$ J Med. (2010) 363:411-22. doi: 10.1056/NEJMoa1001294

6. Troy A, Davidson P, Atkinson C, Hart D. Phenotypic characterisation of the dendritic cell infiltrate in prostate cancer. J Urol. (1998) 160:2149. doi: 10.1016/S0022-5347(01)63093-3

7. Mihalyo MA, Hagymasi AT, Slaiby AM, Nevius EE, Adler AJ. Dendritic cells program non-immunogenic prostate-specific $\mathrm{T}$ cell responses beginning at early stages of prostate tumorigenesis. Prostate. (2007) 67:53646. doi: 10.1002/pros.20549

8. Higham EM, Shen $\mathrm{CH}$, Wittrup KD, Chen J. Cutting edge: delay and reversal of $\mathrm{T}$ cell tolerance by intratumoral injection of antigen-loaded dendritic cells in an autochthonous tumor model. J Immunol. (2010) 184:59548. doi: 10.4049/jimmunol.1000265

9. Drake CG, Doody AD, Mihalyo MA, Huang CT, Kelleher E, Ravi S, et al. Androgen ablation mitigates tolerance to a prostate/prostate cancer-restricted antigen. Cancer Cell. (2005) 7:239-49. doi: 10.1016/j.ccr.2005.01.027

10. Bak SP, Barnkob MS, Bai A, Higham EM, Wittrup KD, Chen J. Differential requirement for CD70 and CD80/CD86 in dendritic cellmediated activation of tumor-tolerized CD8 T cells. J Immunol. (2012) 189:1708-16. doi: 10.4049/jimmunol.1201271

11. Aalamian-Matheis M, Chatta GS, Shurin MR, Huland E, Huland H, Shurin GV. Inhibition of dendritic cell generation and function by serum from prostate cancer patients: correlation with serum-free PSA. Adv Exp Med Biol. (2007) 601:173-82. doi: 10.1007/978-0-387-72005-0_18

12. Fong L, Carroll P, Weinberg V, Chan S, Lewis J, Corman J, et al. Activated lymphocyte recruitment into the tumor microenvironment following preoperative sipuleucel- $\mathrm{T}$ for localized prostate cancer. J Natl Cancer Inst. (2014) 106:dju268. doi: 10.1093/jnci/dj u268

13. Higano CS, Schellhammer PF, Small EJ, Burch PA, Nemunaitis J, Yuh L, et al. Integrated data from 2 randomized, double-blind, placebo-controlled, phase 3 trials of active cellular immunotherapy with sipuleucel-T in advanced prostate cancer. Cancer. (2009) 115:3670-9. doi: 10.1002/cncr.2 4429 contributed to the article and approved the submitted version.

\section{FUNDING}

This work was funded by a Cancer Institute New South Wales Translational Program Grant (11/TPG/3-02). SS was funded by an Australian Postgraduate Award, a Sydney Catalyst Topup Scholarship.

14. Huber ML, Haynes L, Parker C, Iversen P. Interdisciplinary critique of sipuleucel-T as immunotherapy in castration-resistant prostate cancer. J Natl Cancer Inst. (2012) 104:273-9. doi: 10.1093/jnci/djr514

15. Fearnley DB, Whyte LF, Carnoutsos SA, Cook AH, Hart DN. Monitoring human blood dendritic cell numbers in normal individuals and in stem cell transplantation. Blood. (1999) 93:728-36. doi: 10.1182/blood.V93.2.728

16. Sallusto F, Lanzavecchia A. Efficient presentation of soluble antigen by cultured human dendritic cells is maintained by granulocyte/macrophage colony-stimulating factor plus interleukin 4 and downregulated by tumor necrosis factor alpha. J Exp Med. (1994) 179:1109-18. doi: 10.1084/jem.179.4.1109

17. Verdijk P, Aarntzen EHJG, Lesterhuis WJ, Boullart ACI, Kok E, van Rossum MM, et al. Limited amounts of dendritic cells migrate into the T-cell area of lymph nodes but have high immune activating potential in melanoma patients. Clin Cancer Res. (2009) 15:253140. doi: 10.1158/1078-0432.CCR-08-2729

18. Murphy G, Tjoa B, Ragde H, Kenny G, Boynton A. Phase I clinical trial: T-cell therapy for prostate cancer using autologous dendritic cells pulsed with HLA-A0201-specific peptides from prostate-specific membrane antigen. Prostate. (1996) 29:371-80. doi: 10.1002/(SICI)10970045(199612)29:6<371::AID-PROS5>3.0.CO;2-B

19. Murphy GP, Tjoa BA, Simmons SJ, Jarisch J, Bowes VA, Ragde H, et al. Infusion of dendritic cells pulsed with HLA-A2-specific prostate-specific membrane antigen peptides: a phase II prostate cancer vaccine trial involving patients with hormone-refractory metastatic disease. Prostate. (1999) 38:73-8. doi: 10.1002/(SICI)1097-0045(19990101)38:1<73::AID-PRO S9>3.0.CO;2-V

20. Murphy GP, Tjoa BA, Simmons SJ, Ragde H, Rogers M, Elgamal A, et al. Phase II prostate cancer vaccine trial: report of a study involving 37 patients with disease recurrence following primary treatment. Prostate. (1999) 39:54-9. doi: 10.1002/(SICI)1097-0045(19990401)39:1<54::AID-PR OS9>3.0.CO;2-U

21. Murphy GP, Tjoa BA, Simmons SJ, Rogers MK, Kenny GM, Jarisch J. Higher-dose and less frequent dendritic cell infusions with PSMA peptides in hormone-refractory metastatic prostate cancer patients. Prostate. (2000) 43:59-62. doi: 10.1002/(SICI)1097-0045(200 00401)43:1<59::AID-PROS8>3.0.CO;2-D

22. Knight D, Peterson AC, Rini BI, Harlin H, Gajewski TF, Stadler WM. The HLA-A2-restricted PSMA peptide LLHETDSAV is poorly immunogenic in patients with metastatic prostate cancer. Prostate. (2009) 69:1428. doi: $10.1002 /$ pros. 20864

23. Perambakam S, Hallmeyer S, Reddy S, Mahmud N, Bressler L, DeChristopher $\mathrm{P}$, et al. Induction of specific T cell immunity in patients with prostate cancer by vaccination with PSA146-154 peptide. Cancer Immunol Immunother. (2006) 55:1033-42. doi: 10.1007/s00262-005-0090-x

24. Barrou B, Benoit G, Ouldkaci M, Cussenot O, Salcedo M, Agrawal $S$, et al. Vaccination of prostatectomized prostate cancer patients in biochemical relapse, with autologous dendritic cells pulsed with recombinant human PSA. Cancer Immunol Immunother. (2004) 53:453-60. doi: 10.1007/s00262-003-0451-2

25. Pandha HS, John RJ, Hutchinson J, James N, Whelan M, Corbishley C, et al. Dendritic cell immunotherapy for urological cancers using cryopreserved allogeneic tumour lysate-pulsed cells: a phase I/II study. BJU Int. (2004) 94:412-8. doi: 10.1111/j.1464-410X.2004.04922.x 
26. Heiser A, Coleman D, Dannull J, Yancey D, Maurice MA, Lallas CD, et al. Autologous dendritic cells transfected with prostate-specific antigen RNA stimulate CTL responses against metastatic prostate tumors. J Clin Investig. (2002) 109:409-17. doi: 10.1172/JCI0214364

27. Thomas-Kaskel AK, Zeiser R, Jochim R, Robbel C, Schultze-Seemann W, Waller CF, et al. Vaccination of advanced prostate cancer patients with PSCA and PSA peptide-loaded dendritic cells induces DTH responses that correlate with superior overall survival. Int J Cancer. (2006) 119:242834. doi: 10.1002/ijc. 22097

28. Hildenbrand B, Sauer B, Kalis O, Stoll C, Freudenberg MA, Niedermann G, et al. Immunotherapy of patients with hormone-refractory prostate carcinoma pre-treated with interferon-gamma and vaccinated with autologous PSApeptide loaded dendritic cells-a pilot study. Prostate. (2007) 67:5008. doi: 10.1002/pros.20539

29. Zhuang ZX, Shen LQ, Shi Y, Lu X, Shi HZ. Auto-dendritic cell vaccines pulsed with PSA, PSMA and PAP peptides for hormone-refractory prostate cancer. Zhonghua Nan Ke Xue. (2010) 16:698-704.

30. Xi HB, Wang GX, Fu B, Liu WP, Li Y. Survivin and PSMA loaded dendritic cell vaccine for the treatment of prostate cancer. Biol Pharm Bull. (2015) 38:827-35. doi: 10.1248/bpb.b14-00518

31. Fuessel S, Meye A, Schmitz M, Zastrow S, Linne C, Richter K, et al. Vaccination of hormone-refractory prostate cancer patients with peptide cocktail-loaded dendritic cells: results of a phase I clinical trial. Prostate. (2006) 66:811-21. doi: 10.1002/pros.20404

32. Waeckerle-Men Y, Allmen EU, von Moos R, Classon BJ, Scandella E, Schmid HP, et al. Dendritic cells generated from patients with androgen-independent prostate cancer are not impaired in migration and T-cell stimulation. Prostate. (2005) 64:323-31. doi: 10.1002/pros.20231

33. Scheid E, Major P, Bergeron A, Finn OJ, Salter RD, Eady R, et al. TnMUC1 DC vaccination of rhesus macaques and a phase I/II trial in patients with nonmetastatic castrate-resistant prostate cancer. Cancer Immunol Res. (2016) 4:881-92. doi: 10.1158/2326-6066.CIR-15-0189

34. Mu LJ, Kyte JA, Kvalheim G, Aamdal S, Dueland S, Hauser M, et al. Immunotherapy with allotumour mRNA-transfected dendritic cells in androgen-resistant prostate cancer patients. Br J Cancer. (2005) 93:74956. doi: 10.1038/sj.bjc.6602761

35. Reyes D, Salazar L, Espinoza E, Pereda C, Castellon E, Valdevenito R, et al. Tumour cell lysate-loaded dendritic cell vaccine induces biochemical and memory immune response in castration-resistant prostate cancer patients. Br J Cancer. (2013) 109:1488-97. doi: 10.1038/bjc.2013.494

36. Frank MO, Kaufman J, Tian S, Suarez-Farinas M, Parveen S, Blachere NE, et al. Harnessing naturally occurring tumor immunity: a clinical vaccine trial in prostate cancer. PLoS ONE. (2010) 5:e12367. doi: 10.1371/journal.pone.0012367

37. Sonpavde G, McMannis JD, Bai Y, Seethammagari MR, Bull JMC, Hawkins V, et al. Phase I trial of antigen-targeted autologous dendritic cell-based vaccine with in vivo activation of inducible CD40 for advanced prostate cancer. Cancer Immunol Immunother. (2017) 66:134557. doi: 10.1007/s00262-017-2027-6

38. Burch PA, Breen JK, Buckner JC, Gastineau DA, Kaur JA, Laus RL, et al. Priming tissue-specific cellular immunity in a phase I trial of autologous dendritic cells for prostate cancer. Clin Cancer Res. (2000) 6:2175-82.

39. Small EJ, Fratesi P, Reese DM, Strang G, Laus R, Peshwa $\mathrm{MV}$, et al. Immunotherapy of hormone-refractory prostate cancer with antigen-loaded dendritic cells. J Clin Oncol. (2000) 18:3894-903. doi: 10.1200/JCO.2000.18.23.3894

40. Fong L, Brockstedt D, Benike C, Breen JK, Strang G, Ruegg $\mathrm{CL}$, et al. Dendritic cell-based xenoantigen vaccination for prostate cancer immunotherapy. J Immunol. (2001) 167:71506. doi: 10.4049/jimmunol.167.12.7150

41. Fong L, Brockstedt D, Benike C, Wu L, Engleman EG. Dendritic cells injected via different routes induce immunity in cancer patients. J Immunol. (2001) 166:4254-9. doi: 10.4049/jimmunol.166.6.4254

42. Beer TM, Bernstein GT, Corman JM, Glode LM, Hall SJ, Poll WL, et al. Randomized trial of autologous cellular immunotherapy with sipuleucel-T in androgen-dependent prostate cancer. Clin Cancer Res. (2011) 17:455867. doi: 10.1158/1078-0432.CCR-10-3223
43. Prue RL, Vari F, Radford KJ, Tong H, Hardy MY, D’Rozario R, et al. A phase I clinical trial of CD1c (BDCA-1) + dendritic cells pulsed with HLA-A*0201 peptides for immunotherapy of metastatic hormone refractory prostate cancer. J Immunother. (2015) 38:71-6. doi: 10.1097/CJI.0000000000000063

44. Westdorp H, Creemers JHA, van Oort IM, Schreibelt G, Gorris MAJ, Mehra N, et al. Blood-derived dendritic cell vaccinations induce immune responses that correlate with clinical outcome in patients with chemonaive castration-resistant prostate cancer. J Immunother Cancer. (2019) 7:302. doi: 10.1186/s40425-019-0787-6

45. Podrazil M, Horvath R, Becht E, Rozkova D, Bilkova P, Sochorova K, et al. Phase I/II clinical trial of dendritic-cell based immunotherapy (DCVAC/PCa) combined with chemotherapy in patients with metastatic, castration-resistant prostate cancer. Oncotarget. (2015) 6:18192-205. doi: 10.18632/oncotarget.4145

46. Kongsted P, Borch TH, Ellebaek E, Iversen TZ, Andersen R, Met O, et al. Dendritic cell vaccination in combination with docetaxel for patients with metastatic castration-resistant prostate cancer: a randomized phase II study. Cytotherapy. (2017) 19:500-13. doi: 10.1016/j.jcyt.2017.01.007

47. Twardowski P, Wong JYC, Pal SK, Frankel PH, Franklin K, Junqueira M. Randomized phase II trial of sipuleucel-T immunotherapy preceded by sensitizing radiation therapy and sipuleucel-T alone in patients with metastatic castrate resistant prostate cancer. J Clin Oncol. (2017) 35:222. doi: 10.1200/JCO.2017.35.6_suppl.222

48. Antonarakis ES, Kibel AS, Yu EY, Karsh LI, Elfiky A, Shore ND, et al. Sequencing of sipuleucel-T and androgen deprivation therapy in men with hormone-sensitive biochemically recurrent prostate cancer: a phase II randomized trial. Clin Cancer Res. (2017) 23:2451-9. doi: 10.1158/1078-0432.CCR-16-1780

49. Scholz M, Yep S, Chancey M, Kelly C, Chau K, Turner J, et al. Phase I clinical trial of sipuleucel-T combined with escalating doses of ipilimumab in progressive metastatic castrate-resistant prostate cancer. Immunotargets Ther. (2017) 6:11-6. doi: 10.2147/ITT.S122497

50. Fucikova J, Podrazil M, Jarolim L, Bilkova P, Hensler M, Becht E, et al. Phase I/II trial of dendritic cell-based active cellular immunotherapy with DCVAC/PCa in patients with rising PSA after primary prostatectomy or salvage radiotherapy for the treatment of prostate cancer. Cancer Immunol Immunother. (2018) 67:89-100. doi: 10.1007/s00262-017-2068-x

51. Small EJ, Lance RS, Gardner TA, Karsh LI, Fong L, McCoy C, et al. A randomized phase II trial of sipuleucel-T with concurrent versus sequential abiraterone acetate plus prednisone in metastatic castration-resistant prostate cancer. Clin Cancer Res. (2015) 21:38629. doi: 10.1158/1078-0432.CCR-15-0079

52. Rini BI, Weinberg V, Fong L, Conry S, Hershberg RM, Small EJ. Combination immunotherapy with prostatic acid phosphatase pulsed antigen-presenting cells (provenge) plus bevacizumab in patients with serologic progression of prostate cancer after definitive local therapy. Cancer. (2006) 107:6774. doi: $10.1002 /$ cncr.21956

53. Jha GG, Gupta S, Tagawa ST, Koopmeiners JS, Vivek S, Dudek AZ, et al. A phase II randomized, double-blind study of sipuleucel-T followed by IDO pathway inhibitor, indoximod, or placebo in the treatment of patients with metastatic castration resistant prostate cancer (mCRPC). J Clin Oncol. (2017) 35:3066. doi: 10.1200/JCO.2017.35.15_suppl.3066

54. Sim WJ, Malinarich F, Fairhurst AM, Connolly JE. Generation of immature, mature and tolerogenic dendritic cells with differing metabolic phenotypes. J Vis Exp. (2016) 112:54128. doi: 10.3791/54128

55. De Vries IJ, Krooshoop DJ, Scharenborg NM, Lesterhuis WJ, Diepstra JH, Van Muijen GN, et al. Effective migration of antigen-pulsed dendritic cells to lymph nodes in melanoma patients is determined by their maturation state. Cancer Res. (2003) 63:12-7.

56. Draube A, Klein-Gonzalez N, Mattheus S, Brillant C, Hellmich M, Engert $A$, et al. Dendritic cell based tumor vaccination in prostate and renal cell cancer: a systematic review and meta-analysis. PLoS ONE. (2011) 6:e18801. doi: 10.1371/journal.pone.0018801

57. de Vries IJ, Lesterhuis WJ, Scharenborg NM, Engelen LP, Ruiter DJ, Gerritsen MJ, et al. Maturation of dendritic cells is a prerequisite for inducing immune responses in advanced melanoma patients. Clin Cancer Res. (2003) 9:5091100. 
58. Castiello L, Sabatino M, Jin P, Clayberger C, Marincola FM, Krensky AM, et al. Monocyte-derived DC maturation strategies and related pathways: a transcriptional view. Cancer Immunol Immunother. (2011) 60:45766. doi: 10.1007/s00262-010-0954-6

59. Spisek R, Bretaudeau L, Barbieux I, Meflah K, Gregoire M. Standardized generation of fully mature p70 IL-12 secreting monocyte-derived dendritic cells for clinical use. Cancer Immunol Immunother. (2001) 50:41727. doi: $10.1007 / \mathrm{s} 002620100215$

60. Moller I, Michel K, Frech N, Burger M, Pfeifer D, Frommolt P, et al. Dendritic cell maturation with poly(I:C)-based versus PGE2based cytokine combinations results in differential functional characteristics relevant to clinical application. J Immunother. (2008) 31:506-19. doi: 10.1097/CJI.0b013e318177d9e5

61. Muthuswamy R, Urban J, Lee JJ, Reinhart TA, Bartlett D, Kalinski P. Ability of mature dendritic cells to interact with regulatory $T$ cells is imprinted during maturation. Cancer Res. (2008) 68:59728. doi: 10.1158/0008-5472.CAN-07-6818

62. Jongmans W, Tiemessen DM, van Vlodrop IJ, Mulders PF, Oosterwijk E. Th1-polarizing capacity of clinical-grade dendritic cells is triggered by Ribomunyl but is compromised by PGE2: the importance of maturation cocktails. J Immunother. (2005) 28:480-7. doi: 10.1097/01.cji.0000171290.78495.66

63. Verdijk RM, Mutis T, Esendam B, Kamp J, Melief CJ, Brand A, et al. Polyriboinosinic polyribocytidylic acid (poly(I:C)) induces stable maturation of functionally active human dendritic cells. J Immunol. (1999) 163:57-61.

64. Rouas R, Lewalle P, El Ouriaghli F, Nowak B, Duvillier H, Martiat P. Poly(I:C) used for human dendritic cell maturation preserves their ability to secondarily secrete bioactive IL-12. Int Immunol. (2004) 16:76773. doi: 10.1093/intimm/dxh077

65. Hoffmann TK, Meidenbauer N, Muller-Berghaus J, Storkus WJ, Whiteside TL. Proinflammatory cytokines and CD40 ligand enhance cross-presentation and cross-priming capability of human dendritic cells internalizing apoptotic cancer cells. J Immunother. (2001) 24:162-71. doi: 10.1097/00002371-200103000-0 0011

66. Barth RJ Jr, Fisher DA, Wallace PK, Channon JY, Noelle RJ, Gui J, et al. A randomized trial of ex vivo CD40L activation of a dendritic cell vaccine in colorectal cancer patients: tumor-specific immune responses are associated with improved survival. Clin Cancer Res. (2010) 16:554856. doi: 10.1158/1078-0432.CCR-10-2138

67. Gross S, Erdmann M, Haendle I, Voland S, Berger T, Schultz E, et al. Twelveyear survival and immune correlates in dendritic cell-vaccinated melanoma patients. JCI Insight. (2017) 2:e91438. doi: 10.1172/jci.insight.91438

68. Hanks BA, Jiang J, Singh RA, Song W, Barry M, Huls MH, et al. Re-engineered CD40 receptor enables potent pharmacological activation of dendritic-cell cancer vaccines in vivo. Nat Med. (2005) 11:1307. doi: $10.1038 / \mathrm{nm} 1183$

69. Vickers AJ, Brewster SF. PSA velocity and doubling time in diagnosis and prognosis of prostate cancer. Br J Med Surg Urol. (2012) 5:1628. doi: 10.1016/j.bjmsu.2011.08.006

70. Ellis JM, Henson V, Slack R, Ng J, Hartzman RJ, Katovich Hurley C. Frequencies of HLA-A2 alleles in five U.S. population groups. Predominance Of $A^{*} 02011$ and identification of HLA-A*0231. Hum Immunol. (2000) 61:334-40. doi: 10.1016/S0198-8859(99)00 $155-\mathrm{X}$

71. Janssen EM, Lemmens EE, Wolfe T, Christen U, von Herrath MG, Schoenberger SP. CD4+ $\mathrm{T}$ cells are required for secondary expansion and memory in CD8+ $\mathrm{T}$ lymphocytes. Nature. (2003) 421:852-6. doi: 10.1038/nature0 1441

72. Sauter B, Albert ML, Francisco L, Larsson M, Somersan S, Bhardwaj N. Consequences of cell death: exposure to necrotic tumor cells, but not primary tissue cells or apoptotic cells, induces the maturation of immunostimulatory dendritic cells. J Exp Med. (2000) 191:423-34. doi: 10.1084/jem.191.3.423

73. Kotera Y, Shimizu K, Mule JJ. Comparative analysis of necrotic and apoptotic tumor cells as a source of antigen(s) in dendritic cell-based immunization. Cancer Res. (2001) 61:8105-9.
74. Hoffmann TK, Meidenbauer N, Dworacki G, Kanaya H, Whiteside TL. Generation of tumor-specific T-lymphocytes by cross-priming with human dendritic cells ingesting apoptotic tumor cells. Cancer Res. (2000) 60:3542-9.

75. Brusa D, Garetto S, Chiorino G, Scatolini M, Migliore E, Camussi G, et al. Post-apoptotic tumors are more palatable to dendritic cells and enhance their antigen cross-presentation activity. Vaccine. (2008) 26:642232. doi: 10.1016/j.vaccine.2008.08.063

76. Di Nicola M, Napoli S, Anichini A, Mortarini R, Romagnoli L, Magni M, et al. Dendritic cell viability is decreased after phagocytosis of apoptotic tumor cells induced by staurosporine or vaccinia virus infection. Haematologica. (2003) 88:1396-404.

77. Kokhaei P, Choudhury A, Mahdian R, Lundin J, Moshfegh A, Osterborg A, et al. Apoptotic tumor cells are superior to tumor cell lysate, and tumor cell RNA in induction of autologous T cell response in B-CLL. Leukemia. (2004) 18:1810-5. doi: 10.1038/sj.leu.2403517

78. Lundqvist A, Palmborg A, Bidla G, Whelan M, Pandha H, Pisa P. Allogeneic tumor-dendritic cell fusion vaccines for generation of broad prostate cancer T-cell responses. Med Oncol. (2004) 21:155-65. doi: 10.1385/MO:21:2:155

79. Koido S, Homma S, Hara E, Namiki Y, Takahara A, Komita H, et al. Regulation of tumor immunity by tumor/dendritic cell fusions. Clin Dev Immunol. (2010) 2010:516768. doi: 10.1155/2010/516768

80. Lorenc T, Klimczyk K, Michalczewska I, Slomka M, Kubiak-Tomaszewska G, Olejarz W. Exosomes in prostate cancer diagnosis, prognosis and therapy. Int J Mol Sci. (2020) 21:2118. doi: 10.3390/ijms21062118

81. Zhang H, Tang K, Zhang Y, Ma R, Ma J, Li Y, et al. Cellfree tumor microparticle vaccines stimulate dendritic cells via cGAS/STING signaling. Cancer Immunol Res. (2015) 3:196-205. doi: 10.1158/2326-6066.CIR-14-0177

82. Bu N, Wu H, Sun B, Zhang G, Zhan S, Zhang R, et al. Exosome-loaded dendritic cells elicit tumor-specific CD8+ cytotoxic T cells in patients with glioma. J Neurooncol. (2011) 104:659-67. doi: 10.1007/s11060-011-0537-1

83. Tjoa BA, Simmons SJ, Bowes VA, Ragde H, Rogers M, Elgamal A, et al. Evaluation of phase I/II clinical trials in prostate cancer with dendritic cells and PSMA peptides. Prostate. (1998) 36:3944. doi: 10.1002/(SICI)1097-0045(19980615)36:1 <39::AID-PROS6>3.0.CO;26

84. Onishi H, Morisaki T, Baba E, Kuga H, Kuroki H, Matsumoto K, et al. Dysfunctional and short-lived subsets in monocyte-derived dendritic cells from patients with advanced cancer. Clin Immunol. (2002) 105:28695. doi: 10.1006/clim.2002.5293

85. Brusa D, Carletto S, Cucchiarale G, Gontero P, Greco A, Simone M, et al. Prostatectomy restores the maturation competence of blood dendritic cell precursors and reverses the abnormal expansion of regulatory $\mathrm{T}$ lymphocytes. Prostate. (2011) 71:344-52. doi: 10.1002/pros.21248

86. Orange DE, Jegathesan M, Blachere NE, Frank MO, Scher HI, Albert $\mathrm{ML}$, et al. Effective antigen cross-presentation by prostate cancer patients' dendritic cells: implications for prostate cancer immunotherapy. Prostate Cancer Prostatic Dis. (2004) 7:63-72. doi: 10.1038/sj.pcan.4500694

87. Osugi Y, Vuckovic S, Hart DN. Myeloid blood CD11c(+) dendritic cells and monocyte-derived dendritic cells differ in their ability to stimulate $\mathrm{T}$ lymphocytes. Blood. (2002) 100:2858-66. doi: 10.1182/blood.V100.8.2858

88. Fromm PD, Papadimitrious MS, Hsu JL, Van Kooten Losio N, Verma ND, Lo TH, et al. CMRF-56(+) blood dendritic cells loaded with mRNA induce effective antigen-specific cytotoxic T-lymphocyte responses. Oncoimmunology. (2016) 5:e1168555. doi: 10.1080/2162402X.2016.1168555

89. Reizis B, Bunin A, Ghosh HS, Lewis KL, Sisirak V. Plasmacytoid dendritic cells: recent progress and open questions. Annu Rev Immunol. (2011) 29:163-83. doi: 10.1146/annurev-immunol-031210-101345

90. Tel J, Schreibelt G, Sittig SP, Mathan TS, Buschow SI, Cruz LJ, et al. Human plasmacytoid dendritic cells efficiently cross-present exogenous Ags to CD8 + T cells despite lower Ag uptake than myeloid dendritic cell subsets. Blood. (2013) 121:459-67. doi: 10.1182/blood-2012-06-435644

91. Nierkens S, Tel J, Janssen E, Adema GJ. Antigen cross-presentation by dendritic cell subsets: one general or all sergeants? Trends Immunol. (2013) 34:361-70. doi: 10.1016/j.it.2013.02.007

92. Villani AC, Satija R, Reynolds G, Sarkizova S, Shekhar K, Fletcher J, et al. Single-cell RNA-seq reveals new types of human blood 
dendritic cells, monocytes, and progenitors. Science. 356:eaah4573. doi: 10.1126/science.aah4573

93. Collin M, Bigley V. Human dendritic cell subsets: an update. Immunology. (2018) 154:3-20. doi: 10.1111/imm.12888

94. Sheikh NA, Petrylak D, Kantoff PW, Dela Rosa C, Stewart FP, Kuan LY, et al. Sipuleucel-T immune parameters correlate with survival: an analysis of the randomized phase 3 clinical trials in men with castrationresistant prostate cancer. Cancer Immunol Immunother. (2013) 62:13747. doi: $10.1007 / \mathrm{s} 00262-012-1317-2$

95. Bachem A, Guttler S, Hartung E, Ebstein F, Schaefer M, Tannert A, et al. Superior antigen cross-presentation and XCR1 expression define human $\mathrm{CD} 11 \mathrm{c}+\mathrm{CD} 141+$ cells as homologues of mouse CD8+ dendritic cells. J Exp Med. (2010) 207:1273-81. doi: 10.1084/jem.20100348

96. Gerner MY, Casey KA, Mescher MF. Defective MHC class II presentation by dendritic cells limits CD4 T cell help for antitumor CD8 T cell responses. J Immunol. (2008) 181:155-64. doi: 10.4049/jimmunol.181.1.155

97. Zhu Z, Cuss SM, Singh V, Gurusamy D, Shoe JL, Leighty R, et al. CD4+ T cell help selectively enhances high-avidity tumor antigen-specific CD8+ T cells. J Immunol. (2015) 195:3482-9. doi: 10.4049/jimmunol.1401571

98. Srivastava MK, Dubinett S, Sharma S. Targeting MDSCs enhance therapeutic vaccination responses against lung cancer. Oncoimmunology. (2012) 1:165051. doi: 10.4161/onci.21970

99. Bonifaz L, Bonnyay D, Mahnke K, Rivera M, Nussenzweig MC, Steinman RM. Efficient targeting of protein antigen to the dendritic cell receptor DEC-205 in the steady state leads to antigen presentation on major histocompatibility complex class I products and peripheral CD8+ T cell tolerance. J Exp Med. (2002) 196:1627-38. doi: 10.1084/jem.20021598

100. Bonifaz LC, Bonnyay DP, Charalambous A, Darguste DI, Fujii S, Soares $\mathrm{H}$, et al. In vivo targeting of antigens to maturing dendritic cells via the DEC-205 receptor improves T cell vaccination. J Exp Med. (2004) 199:81524. doi: $10.1084 /$ jem. 20032220

101. Bozzacco L, Trumpfheller C, Huang Y, Longhi MP, Shimeliovich I, Schauer JD, et al. HIV gag protein is efficiently cross-presented when targeted with an antibody towards the DEC-205 receptor in Flt3 ligand-mobilized murine DC. Eur J Immunol. (2010) 40:36-46. doi: 10.1002/eji.200939748

102. Gurer C, Strowig T, Brilot F, Pack M, Trumpfheller C, Arrey F, et al. Targeting the nuclear antigen 1 of Epstein-Barr virus to the human endocytic receptor DEC-205 stimulates protective T-cell responses. Blood. (2008) 112:12319. doi: 10.1182/blood-2008-03-148072

103. Hawiger D, Inaba K, Dorsett $Y$, Guo M, Mahnke K, Rivera M, et al. Dendritic cells induce peripheral $\mathrm{T}$ cell unresponsiveness under steady state conditions in vivo. J Exp Med. (2001) 194:769-79. doi: 10.1084/jem.194.6.769

104. Idoyaga J, Lubkin A, Fiorese C, Lahoud MH, Caminschi I, Huang $\mathrm{YX}$, et al. Comparable $\mathrm{T}$ helper 1 (Th1) and $\mathrm{CD} 8 \mathrm{~T}$-cell immunity by targeting HIV gag p24 to CD8 dendritic cells within antibodies to Langerin, DEC205, and Clec9A. Proc Natl Acad Sci USA. (2011) 108:238489. doi: $10.1073 /$ pnas. 1019547108

105. Dhodapkar MV, Sznol M, Zhao B, Wang D, Carvajal RD, Keohan ML, et al. Induction of antigen-specific immunity with a vaccine targeting NYESO-1 to the dendritic cell receptor DEC-205. Sci Transl Med. (2014) 6:232ra51. doi: 10.1126/scitranslmed.3008068

106. Sancho D, Mourao-Sa D, Joffre OP, Schulz O, Rogers NC, Pennington DJ, et al. Tumor therapy in mice via antigen targeting to a novel, DC-restricted C-type lectin. J Clin Invest. (2008) 118:2098-110. doi: 10.1172/JCI34584

107. Mastelic-Gavillet B, Sarivalasis A, Lozano LE, Wyss T, Inoges S, de Vries IJM, et al. Quantitative and qualitative impairments in dendritic cell subsets of patients with ovarian or prostate cancer. Eur J Cancer. (2020) 135:17382. doi: 10.1016/j.ejca.2020.04.036

108. D'Apice L, Costa V, Sartorius R, Trovato M, Aprile M, De Berardinis P. Stimulation of innate and adaptive immunity by using filamentous bacteriophage FD targeted to DEC-205. J Immunol Res. (2015) 2015:585078. doi: 10.1155/2015/585078

109. Sartorius R, Bettua C, D'Apice L, Caivano A, Trovato M, Russo D, et al. Vaccination with filamentous bacteriophages targeting DEC-205 induces DC maturation and potent anti-tumor T-cell responses in the absence of adjuvants. Eur J Immunol. (2011) 41:2573-84. doi: 10.1002/eji.201141526

110. Tenbusch M, Nchinda G, Storcksdieck genannt Bonsmann M, Temchura $\mathrm{V}$, Uberla K. Targeting the antigen encoded by adenoviral vectors to the
DEC205 receptor modulates the cellular and humoral immune response. Int Immunol. (2013) 25:247-58. doi: 10.1093/intimm/dxs112

111. Cruz LJ, Tacken PJ, Fokkink R, Joosten B, Stuart MC, Albericio F, et al. Targeted PLGA nano- but not microparticles specifically deliver antigen to human dendritic cells via DC-SIGN in vitro. J Control Release. (2010) 144:118-26. doi: 10.1016/j.jconrel.2010.02.013

112. Manolova V, Flace A, Bauer M, Schwarz K, Saudan P, Bachmann MF. Nanoparticles target distinct dendritic cell populations according to their size. Eur J Immunol. (2008) 38:1404-13. doi: 10.1002/eji.200737984

113. Ma W, Chen M, Kaushal S, McElroy M, Zhang Y, Ozkan C, et al. PLGA nanoparticle-mediated delivery of tumor antigenic peptides elicits effective immune responses. Int J Nanomedicine. (2012) 7:147587. doi: $10.2147 /$ IJN.S29506

114. Chen Q, Bao Y, Burner D, Kaushal S, Zhang Y, Mendoza T, et al. Tumor growth inhibition by mSTEAP peptide nanovaccine inducing augmented CD8(+) T cell immune responses. Drug Deliv Transl Res. (2019) 9:1095105. doi: $10.1007 / \mathrm{s} 13346-019-00652-\mathrm{z}$

115. Cruz LJ, Rosalia RA, Kleinovink JW, Rueda F, Lowik CW, Ossendorp F. Targeting nanoparticles to CD40, DEC-205 or CD11c molecules on dendritic cells for efficient CD8(+) T cell response: a comparative study. J Control Release. (2014) 192:209-18. doi: 10.1016/j.jconrel.2014.07.040

116. Rosalia RA, Cruz LJ, van Duikeren S, Tromp AT, Silva AL, Jiskoot $\mathrm{W}$, et al. CD40-targeted dendritic cell delivery of PLGA-nanoparticle vaccines induce potent anti-tumor responses. Biomaterials. (2015) 40:8897. doi: 10.1016/j.biomaterials.2014.10.053

117. Kitamura H, Torigoe T, Asanuma H, Honma I, Sato N, Tsukamoto T. Down-regulation of HLA class I antigens in prostate cancer tissues and up-regulation by histone deacetylase inhibition. J Urol. (2007) 178:6926. doi: 10.1016/j.juro.2007.03.109

118. Seliger B, Stoehr R, Handke D, Mueller A, Ferrone S, Wullich B, et al. Association of HLA class I antigen abnormalities with disease progression and early recurrence in prostate cancer. Cancer Immunol Immunother. (2010) 59:529-40. doi: 10.1007/s00262-009-0769-5

119. Ahmed MM, Hodge JW, Guha C, Bernhard EJ, Vikram B, Coleman $\mathrm{CN}$. Harnessing the potential of radiation-induced immune modulation for cancer therapy. Cancer Immunol Res. (2013) 1:280-4. doi: 10.1158/2326-6066.CIR-13-0141

120. Hodge JW, Garnett CT, Farsaci B, Palena C, Tsang KY, Ferrone S, et al. Chemotherapy-induced immunogenic modulation of tumor cells enhances killing by cytotoxic $\mathrm{T}$ lymphocytes and is distinct from immunogenic cell death. Int J Cancer. (2013) 133:624-36. doi: 10.1002/ijc.28070

121. Leclerc BG, Charlebois R, Chouinard G, Allard B, Pommey S, Saad F, et al. CD73 expression is an independent prognostic factor in prostate cancer. Clin Cancer Res. (2016) 22:158-66. doi: 10.1158/1078-0432.CCR-15-1181

122. Yunger S, Bar El A, Zeltzer LA, Fridman E, Raviv G, Laufer M, et al. Tumor-infiltrating lymphocytes from human prostate tumors reveal anti-tumor reactivity and potential for adoptive cell therapy. Oncoimmunology. (2019) 8:e1672494. doi: 10.1080/2162402X.2019.167 2494

123. Kiniwa Y, Miyahara Y, Wang HY, Peng W, Peng G, Wheeler TM, et al. CD8+ Foxp3+ regulatory $\mathrm{T}$ cells mediate immunosuppression in prostate cancer. Clin Cancer Res. (2007) 13:6947-58. doi: 10.1158/1078-0432.CCR-07-0842

124. Sheikh N, Cham J, Zhang L, DeVries T, Letarte S, Pufnock J, et al. Clonotypic diversification of intratumoral $\mathrm{T}$ cells following sipuleucel$\mathrm{T}$ treatment in prostate cancer subjects. Cancer Res. (2016) 76:37118. doi: 10.1158/0008-5472.CAN-15-3173

125. Hagihara K, Chan S, Zhang L, Oh DY, Wei XX, Simko J, et al. Neoadjuvant sipuleucel-T induces both Th1 activation and immune regulation in localized prostate cancer. Oncoimmunology. (2019) 8:e1486953. doi: 10.1080/2162402X.2018.148 6953

126. Hansen AR, Massard C, Ott PA, Haas NB, Lopez JS, Ejadi S, et al. Pembrolizumab for advanced prostate adenocarcinoma: findings of the KEYNOTE-028 study. Ann Oncol. (2018) 29:1807-13. doi: 10.1093/annonc/mdy232

127. Fizazi K, Drake CG, Beer TM, Kwon ED, Scher HI, Gerritsen WR, et al. Final analysis of the ipilimumab versus placebo following radiotherapy phase III trial in postdocetaxel metastatic castration-resistant prostate cancer 
identifies an excess of long-term survivors. Eur Urol. (2020) 78:82230. doi: 10.1016/j.eururo.2020.07.032

128. McNeel DG, Eickhoff JC, Wargowski E, Zahm C, Staab MJ, Straus J, et al. Concurrent, but not sequential, PD-1 blockade with a DNA vaccine elicits anti-tumor responses in patients with metastatic, castration-resistant prostate cancer. Oncotarget. (2018) 9:25586-96. doi: 10.18632/oncotarget.25387

129. Wada S, Yoshimura K, Hipkiss EL, Harris TJ, Yen HR, Goldberg $\mathrm{MV}$, et al. Cyclophosphamide augments antitumor immunity: studies in an autochthonous prostate cancer model. Cancer Res. (2009) 69:430918. doi: 10.1158/0008-5472.CAN-08-4102

130. Comito G, Giannoni E, Segura CP, Barcellos-de-Souza P, Raspollini MR, Baroni G, et al. Cancer-associated fibroblasts and M2-polarized macrophages synergize during prostate carcinoma progression. Oncogene. (2014) 33:242331. doi: 10.1038/onc.2013.191

131. Gannon PO, Poisson AO, Delvoye N, Lapointe R, Mes-Masson AM, Saad F. Characterization of the intra-prostatic immune cell infiltration in androgen-deprived prostate cancer patients. J Immunol Methods. (2009) 348:9-17. doi: 10.1016/j.jim.2009.06.004

132. Erlandsson A, Carlsson J, Lundholm M, Falt A, Andersson SO, Andren O, et al. M2 macrophages and regulatory T cells in lethal prostate cancer. Prostate. (2019) 79:363-369. doi: 10.1002/pros.23742

133. Cortesi F, Delfanti G, Grilli A, Calcinotto A, Gorini F, Pucci F, et al. Bimodal CD40/Fas-dependent crosstalk between iNKT cells and tumor-associated macrophages impairs prostate cancer progression. Cell Rep. (2018) 22:300620. doi: $10.1016 /$ j.celrep.2018.02.058

134. Zheng T, Ma G, Tang M, Li Z, Xu R. IL-8 Secreted from M2 macrophages promoted prostate tumorigenesis via STAT3/MALAT1 pathway. Int J Mol Sci. (2018) 20:27. doi: 10.3390/ijms20010098

135. Wang C, Peng G, Huang H, Liu F, Kong DP, Dong KQ, et al. Blocking the feedback loop between neuroendocrine differentiation and macrophages improves the therapeutic effects of enzalutamide (MDV3100) on prostate cancer. Clinical Cancer Research. (2018) 24:70823. doi: 10.1158/1078-0432.CCR-17-2446

136. Santegoets SJ, Stam AG, Lougheed SM, Gall H, Jooss K, Sacks $\mathrm{N}$, et al. Myeloid derived suppressor and dendritic cell subsets are related to clinical outcome in prostate cancer patients treated with prostate GVAX and ipilimumab. J Immunother Cancer. (2014) 2:31. doi: $10.1186 / s 40425-014-0031-3$
137. Kodumudi KN, Woan K, Gilvary DL, Sahakian E, Wei S, Djeu JY. A novel chemoimmunomodulating property of docetaxel: suppression of myeloid-derived suppressor cells in tumor bearers. Clin Cancer Res. (2010) 16:4583-94. doi: 10.1158/1078-0432.CCR-10-0733

138. Schellhammer PF, Chodak G, Whitmore JB, Sims R, Frohlich MW, Kantoff PW. Lower baseline prostate-specific antigen is associated with a greater overall survival benefit from sipuleucel- $T$ in the immunotherapy for prostate adenocarcinoma treatment (IMPACT) trial. Urology. (2013) 81:1297-302. doi: 10.1016/j.urology.2013.0 1.061

139. Kissick HT, Sanda MG, Dunn LK, Pellegrini KL, On ST, Noel JK, et al. Androgens alter T-cell immunity by inhibiting T-helper 1 differentiation. Proc Natl Acad Sci USA. (2014) 111:9887-92. doi: 10.1073/pnas.140246 8111

140. Dallos M, Obradovic A, Chowdhury N, Bujanda ZL, Aggen DH, Hawley J, et al. Human prostate cancer immune phenotypes after androgen deprivation therapy. J Clin Oncol. (2019) 37:5083. doi: 10.1200/JCO.2019.37.15_suppl. 5083

141. Flammiger A, Weisbach L, Huland H, Tennstedt P, Simon R, Minner S, et al. High tissue density of FOXP3 $+\mathrm{T}$ cells is associated with clinical outcome in prostate cancer. Eur J Cancer. (2013) 49:1273-9. doi: 10.1016/j.ejca.2012.1 1.035

142. Shen YC, Ghasemzadeh A, Kochel CM, Nirschl TR, Francica BJ, LopezBujanda ZA, et al. Combining intratumoral Treg depletion with androgen deprivation therapy (ADT): preclinical activity in the Myc-CaP model. Prostate Cancer Prostatic Dis. (2018) 21:113-25. doi: 10.1038/s41391-017-0 013-x

Conflict of Interest: The authors declare that the research was conducted in the absence of any commercial or financial relationships that could be construed as a potential conflict of interest.

Copyright (c) 2021 Sutherland, Ju, Horvath and Clark. This is an open-access article distributed under the terms of the Creative Commons Attribution License (CC BY). The use, distribution or reproduction in other forums is permitted, provided the original author(s) and the copyright owner(s) are credited and that the original publication in this journal is cited, in accordance with accepted academic practice. No use, distribution or reproduction is permitted which does not comply with these terms. 